\title{
Transient Modeling of Hybrid Rocket Low Frequency Instabilities
}

\author{
M. Arif Karabeyogh", Shane De Zihw', Brian Cantweit and Greg Ziniex"
}

\section{Abstract}

A comprebensive dynamic model of a hybrid rocket hes been developed in ander so understad and predict the transiem behavior including instabilities. A linearized version of the transient model predicted the low-frequency chanber pressure oscillations the are commonly observed in hybridk The sower of the instabilities is based on a complex coupling of thermal transients in the solid fuel, wall heat transfer blocking

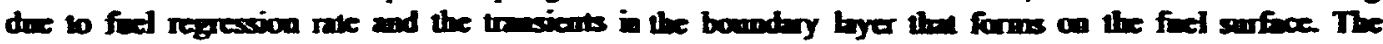
oscillation frequencies predicted by the linearized theory are in very good agreement with 43 motor test results oberined from the bybid propenbion hiterature. The motor lest results used in the comperison cover a very wide spectrum of parameters inchuding: 1) four separate research and development programs, 2) three

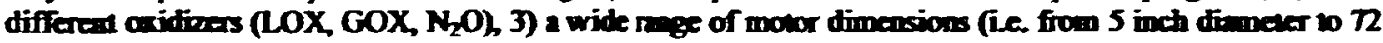
inch diameter) and operating conditions and 4) several fucl formulations. A simple universal scaling formula for the frequency of the primary osciltation mode is saggested

\section{1) Nomenclature:}

\begin{tabular}{|c|c|}
\hline$A=$ & $\begin{array}{l}\text { Pre-exponamial coeficicien } \\
\text { Pot }\end{array}$ \\
\hline $\begin{array}{l}B: \\
C:\end{array}$ & $\begin{array}{l}\text { Blowing perineler } \\
\text { Spocific bect of fed }\end{array}$ \\
\hline$c^{\prime}=$ & $\begin{array}{l}\text { Bondary byo dety tixe } \\
\text { coefficion }\end{array}$ \\
\hline$C_{f}, C_{H}=$ & $\begin{array}{l}\text { Sin fiction coefficien and Standen } \\
\text { nurber }\end{array}$ \\
\hline & 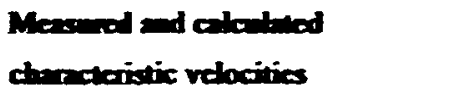 \\
\hline
\end{tabular}

$\bar{D}:$

$\boldsymbol{E}_{\text {. }}:$

$E_{L}, E_{E_{F}}$

$f, f_{1-L}=$

$F_{T}:$

$F_{\boldsymbol{T}}:$

$G_{0,}, G_{s}=$

h, L
Averize port diencier

Activation calory

Encky Parancters

Primer oxcillation froquency, firt acoustic mode frequen

Theral syster tres sor fention

Thermalcombetion coupled

system irmader fation

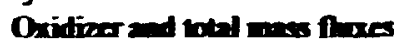

Towal and ben beses of grificaion

\begin{tabular}{|c|c|}
\hline$k$ : & Blowing parameter exponemt \\
\hline$i=$ & $\begin{array}{l}\text { Leplace trasfore of cridied mess } \\
\text { Mex pertutation }\end{array}$ \\
\hline$L, L_{m}=$ & Length of the foel pont and worar \\
\hline $\boldsymbol{L}^{*}:$ & $V_{m} / A_{m}$ \\
\hline$\dot{m}_{0}, \dot{m}_{1}=$ & Oxidicer and tobal moss flow rite \\
\hline : & Mas f nx exponed \\
\hline$O / F:$ & Oxidieer to finel ratio \\
\hline$P_{c}:$ & Averged donber presere \\
\hline $\boldsymbol{Q}_{\boldsymbol{r}}, \boldsymbol{Q}_{\mathbf{r}}:$ & Cosvative and hat wal heat \\
\hline$\dot{\boldsymbol{r}}, \boldsymbol{R}:$ & $\begin{array}{l}\text { Thres } \\
\text { Dimensiond and nontdimeasional } \\
\text { regresion rete }\end{array}$ \\
\hline $\mathbf{R e}_{z}:$ & Regrolds nomber \\
\hline$R_{z} R_{2}=$ & Specific and wiversal gas constants \\
\hline $\boldsymbol{R T} T_{m}=$ & $\begin{array}{l}\text { Avarage constant lonperdure } \\
\text { product }\end{array}$ \\
\hline$s:$ & Laphoce trassforn varible \\
\hline $1=$ & $\operatorname{Time}$ \\
\hline$r:$ & Temperibure \\
\hline $\boldsymbol{U}^{*}:$ & Difísic specd \\
\hline
\end{tabular}

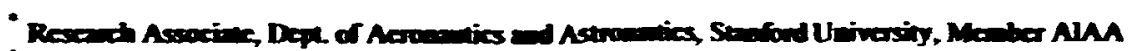

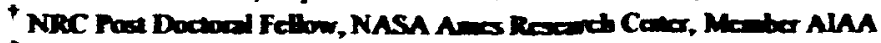

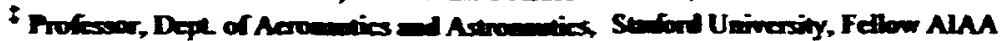

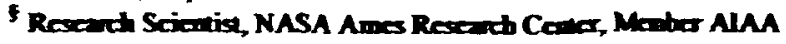




\begin{tabular}{|c|c|}
\hline$V_{p}, V_{m}=$ & Pont and motor volimes \\
\hline $\begin{array}{l}z= \\
\delta:\end{array}$ & $\begin{array}{l}\text { Axial distance dong the port } \\
\text { Booudary byer thectuess }\end{array}$ \\
\hline$\Delta \boldsymbol{P}_{\text {ace }}:$ & $\begin{array}{l}\text { Chamber pressore oscillatioa } \\
\text { amplitide }\end{array}$ \\
\hline$r:$ & Ratio of specific heots \\
\hline$x:$ & Themel diffusivity of foel \\
\hline$\rho_{\boldsymbol{f}}, \boldsymbol{\rho}:$ & Fod and averye ges densities \\
\hline$\tau_{W}, \tau_{A}=$ & 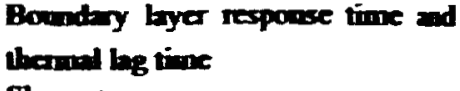 \\
\hline$\tau_{-}:$ & Sheer siress \\
\hline$\sigma_{1}, \sigma_{2}$ & Ges phese roponse coefficicants \\
\hline $\boldsymbol{\mu}:$ & Average gos viscosity \\
\hline \multicolumn{2}{|l|}{ Sobscripex } \\
\hline$a=$ & Ambien \\
\hline 1: & Fise patubion varible \\
\hline$e:$ & Free stren value \\
\hline ref : & Refarace quatities \\
\hline $\mathbf{s}:$ & Sarface \\
\hline \multicolumn{2}{|l|}{ Stpetscipes: } \\
\hline 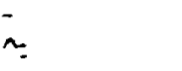 & 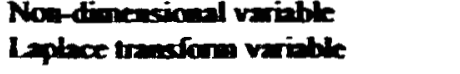 \\
\hline
\end{tabular}

2) Intronution:

The allowable trat ocilluion for an opertional propulaion syolen are Ficied by certin practical considertions indatis acoelerrion loads on the velicle structes and atso on the

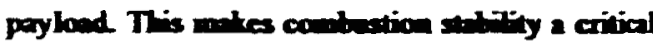

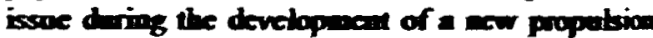
systen. The conbetion incturinies of solid and lipoid systems bave bece studied in deplh and pertially seccessfol thoories along with certin practical roles for designing stble systems have been developed ${ }^{123}$. Even with this excosive lnowledige bese developonca of stable roctet systems rousios sig if resounces dering the decig and tatis pheses of a

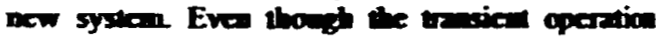
and instabitity modusins of bybits lewe a been explored as exarivety as the more moture chemical systerins, part coproicance shows th hybrids do not bive the corotrophic inobitive the Ixpid and solid systems my poecutially present

In fact, hybid sysicans typically show finite anplitude (i.e. 2-20\% nns of mean chenber pressure) low-frequency chanbes pressare

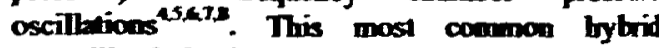
instabitity is in the form of limit cycle oscillations with frequencies much smaller thos the firt longiturfind acoustic mode of the conbustion chomber.

Eva though the and case of the bow frequency bybrid inombitios is not yat kown, a few phesible theoric exist5ialle. Most of the

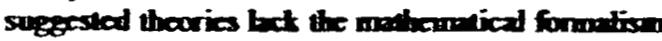
that exists in the sotod and liquid instabifity modek. The foudameneal fificuly is producing a mecharion of would geacrile instabifities comes from the for then lybid bern ries are typically indepeaded of the clumber preserere This for

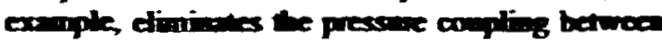
The thermal bos in the solid and the chanber gos dyminic which is the sondce of the $L$ * instubitives in sofid rockets'.

One particaler theary, the TC couplod model'14, which is besed on the compling of themol bes in the solid and the log in the ges

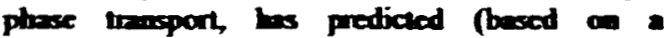
mathenetiod formation) fod mos production oscillations the wonld dive the observed prosine oscillations The papose of this paper is 10 corond the TC corpled theory to inctede the effects of the chamber ges dyranics and compare the theary prodictions with the monor lest dath The maits and shoroconing of the TC coupled model will also be discused

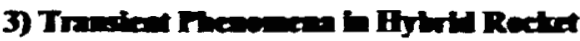
Mens:

Our approect to modefing the dynewaic behevior of bybrits is 10 isolute the sabsysters of the moer and consider every single subsysten indivitanlly. For a fal description of mold transients one has in consider the following subsystems.

a) Feal Systere in a hybrid motor, the fiquid (or gaseons) oxidizer meods to be fod in to the

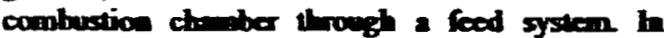
relity the feed system respoese tine is finite dece to the copacity of the elements in the systen. Acome response doponds on the detaits of the systen, which is Rely to be significenly difierent fir every design. For this reason we will bypass the feod sysecm dynamies in our ivestigations by assouming the corified mess fow rne as the inper peremeter. This is a resomble asomplion for most systens bocase isoteing demos (ie crituting venture, sonic onifice) are presene

b) Vapariontion of the linis Orificer: Conplete vaporization of the oxidizer droplets in 
the combustion chamber requires a certain charrecteristic time dependiag on perameters sach as the droplet size and the thermal/flow ervironman of the space where droplet vaporization takes place. For the purposes of this peper we will assume the the oxidizer is in greans phase when it enters the port.

c) Difiusion and Combastion in the Bonndary Laver: It ropiries some time for the hybrid boundary layer properties to adjust to the changes in the pon velocity or the fivel blowing from the surface. The asocisted dynamics has been discresed in detil in Refk 13, 14 and will be briefly covered in section 5 of this paper.

d) Thenenl Reoposse in the Solid Grain: A chroge in the wall beal flux to the bybrid fael grain can not be followed immediately by fuel production due to the finite beat capacity of the solid foel.

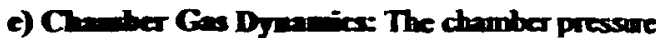
responds to the changes in the mass flow with a time scale proportional to the filling time of the chember. Aconstic response is also resolved in this sub-systan.

In the sibsechen sections the lad three of these sebsysten (sections c-e) will be modeded

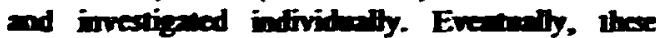
suboysters will be coupled to give the overn system response. The order of maginde catinates of the time scales of some of the iportum processes emon mered in a typical bybid mokor are listed in Table 1. h an modefing solid and

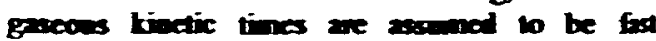
compered to the other releven time sales.
4) Therion Log Moded:

The regression rate of the hybrid fuel grain cannot respond to the changes in the surface hea flux instantaneonsty due to the finite thermal conductivity of the solid fuel. A complene transina model for a hybrid rocket system requires a dynamic model to predict the regression rete history for a given wall heat flux schedule. In order to serve this pupose a thermal be model tha models the nonlinear heat conduction in the fuel grain with a moving boundery has bees fonmalned and reported in Refs.13 and 14. The schematic of this particubar model is shown in Fizare 1.

In the thermal bg model, the gasification and pyrotysis reactions at the surface are both modeled by an exponertial expression of the Armenius type. For chemical reactions, the exponcutial constan is an ativation cachy, whereas in vaporization it is the latent heat In order to describe this behavior, we assign an average effective activation energy, $E_{a}$, resulting in:

$$
\bar{r}=A e^{-E_{0} / 2 \pi,}
$$

Here $T_{s}$ is the serface kempernture, $r$ is the regrasion race and $R_{\text {o }}$ is the univers gas conston The melowical formation and varios solation tochniqu for the themel be woded are presented in Ref 13. One solution of interest is obtained by perturbing the fill nonlinear system around the nominal operaing point The finear initial-boundary value problem defined for the first onder pertubetion qumities bes been solved with use of the Laplace transformation lochnique. The trassfer function betweca the regrosion rate

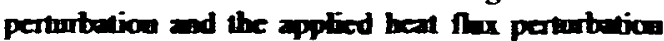
can be writion as

$$
F_{T}=\frac{\hat{R}_{1}(s)}{\hat{Q}_{1}(s)}=\frac{2 E_{E_{s}} s}{(1+\sqrt{4 s+1})\left(s+E_{E_{s}}\right)-2 E_{E_{0}}+2 E_{1} E_{E_{s}} s} .
$$

Nole that $\hat{R}_{4}(s)$ and $\hat{Q}_{1}(s)$ are the

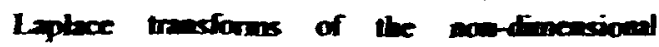
regrescion rice pertubation and the wh hed thax pertubation, respectivety. Here the following now dimersional parancters are defined for converience.

$$
\begin{aligned}
& E_{E_{-}}=\frac{E_{Q} \Delta T}{R_{Q}\left(T_{s}\right)_{\text {id }}^{2}} \quad E_{L}=\frac{L}{C \Delta T} \\
& \Delta T=\left(T_{s}\right)_{\text {nff }}-T_{\text {e }} \quad \bar{Q}=\frac{\dot{Q}_{r}}{\dot{Q}_{\text {ref }}} \\
& R=\dot{r} / \dot{r}_{\text {nd }} \quad \dot{Q}_{\text {ng }}=\dot{r}_{\text {ref }} \rho_{f} C A T
\end{aligned}
$$


The refereace-state indicated by subscript "reP" conesponds to the nominal operating point around which the system is perturbed.

Equation 2 relates the wall heat flux to the regression rate in the Laplace space and establishcs one block in our overall transient model that is shown schematically in Figure 2. Various important characteristics of a lincar system including stability can be inferred from the denominator of its transfer function commonly referred as the characteristic equation, This transfer function for the thermal systcrn, which contains a square root term, produces a phase lead between the heat flux and the regression rate in the low end of the frequency domai/233. As it will be discussed in the following sections, this phase Icad capability will play a critical role in the production of low frequency instabilities.

\section{5) Gas Phase Combustion Model:}

In the themal lag model we have treated the surface heat flux as a parameter that can directly be controlled. However, in a hybrid motor, the oxidizer mass flow rate is the primary input variable that can be controlled directly. The actual response of the motor to a change in the oxidizer mass flow is rather complicated during a transient. As the oxidizer mass flow rate of the motor changes, the mass flux at a characteristic point in the port reacts to the cliange as does the turbulent boundary layer developed over the fuel surface. In this section we will summarize the modeling of the boundary layer combustion dynamics and investigate its interactions with the thermal lags in the solid. For the sake of sinuplicity, we will ignore the radiative heat transfer to the fuel surface, which is typically a relatively small fraction of the total heat flux. Unless the radiation dominates the convection component of the surface heat transfer, the transient model developed in this paper is expected to be valid.

In our preliminary model we assume that the boundary-layer response is quasi-steady, namely the boundary-layer diffusion lag times are small compared to the thermal lag times in the solid. Under the quasi-steady assumption one can use the classical approach ${ }^{15}$ to calculate the response of the wall heat flux to the changes in mass flux. However, the results of classical hybrid theory cannot be used directly during a transient in the solid, due to the fact that the convective heat transfer to the wall depends explicitly on the instantaneous regression rate through the blocking generated by the blowing of the gaseous fuel from the surface. In the presence of the thermal lags, the blocking generates a coupling mechanism in the gas phase between the regression rate and the heat flow to the surface. Based on this understanding. the classical theory can be modified to obtain a functional relation between wall heat flux and oxidizer mass flux-regression rate combination in terms of non-dimensional parameters:

$$
\overline{\dot{Q}}_{c}(\bar{t})=E_{L} \bar{G}_{o}^{n /(1-k)} R^{-k /(1-k)}
$$

Note that $\bar{G}_{o}=G_{o} /\left(G_{o}\right)_{\text {ref }}, \bar{Q}_{c}=\dot{Q}_{c} / \dot{Q}_{\text {ref }}$ and $n$ is the oxidizer flux exponent, $k$ is the blowing correction exponent first defined by Marxman (i.e. $\left.C_{H} / C_{H_{0}}=B^{k}\right)$. Here the local total mass flux that appears in the original Marxman formulation is replaced by the oxidizer mass flux for convenience. The justification for that transformation is given in Ref. 14,

Thus far in the development of the transient bybrid combustion theory we assumed that the boundary layer responds rapidly to the changes in the mass flux compared to the other transient time scalcs in the rocket motor such as the gas dynamic lags or the thermal lags. This assumption fails to be valid especially for largc hybrid motors. In order to develop a realistic model for the dynamics of the hybrid motor, the boundary layer lags must be considered. Since this complex dynamic phenomenon is extremely difficult to investigate both theoretically and experimentally, we consider the simpler cases reported in the literature of an incompressible turbulent boundary layer with no blowing or chemical reactions ${ }^{16}$. The most important conclusion for this simplified case is that the time required for transition from the initial equilibrium proffle to the final equilibrium profile at any axial location, 2 , is proportional to the time of flight of a fluid particle from the leading edige of the boundary layer to the specific axial location at the speed of the free strearn flow, $u_{e}$. This very important result can be formulated for hybrid boundary layers as

$$
\tau_{b l}=c^{\prime} \frac{\Sigma}{u_{\varepsilon}}
$$

Here $c^{\prime}$ is a constant that needs to be detenmined empirically. We will call this time required for equilibration, the characteristic response time of the boundary layer, $\tau_{b l}$. It is 
important to note that the physical nature of the boundary layer transient time is not related to the propagation of the disturbances with the speed of the port velocity as suggested by Equation 4 . The delay rather depends on the diffusion time scale across the boundary layer which is proportional to the ratio of the local boundary layer thickness to the diffusion speed, $\tau_{b l} \cong \delta / U^{\prime \prime}$. The diffusion speed is defined in terms of the shcar stress and mean gas density as $U^{*}=\sqrt{\tau_{0} / P}$. The boundary layer delay time, after the substitution of the standard (incompressible) turbulent boundary layer expressions $^{17}$ for the shear stress, $\tau_{0}=0.0288 \rho u_{e} \operatorname{Re}_{z}^{-0.2}$, and the thickness, $\delta=0.37 z \mathrm{Rc}_{z}^{-0.2}$, becomes $\tau_{b i}=2.18 \mathrm{Rc}_{z}^{-0.1} z / u_{c}$. Here the local Reynolds number is defined as $\operatorname{Re}_{z}=u_{e}=\rho / \mu$. Note that the coefficient $c^{\prime}$ is found to be a weak function of the local Reynolds number. Thus, for simplicity, we assume that $c^{\prime}$ is constant. For Reynolds numbers corresponding to typical hybrid operation, $c^{\prime}$ is estimated to be approximately 0.55 . In a real hybrid boundary layer with combustion and blowing, $c^{\prime}$ can be different from this estimation and for that reason, it is determined empirically.

For the purpose of this paper, it is convenient to consider an average boundary layer delay and replace the local distance 2 , with the half of the grain length, $L / 2$. Note that the empirical constant $c^{r}$ accounts for the correction to the inaccurate selection of the length scale, $L$. However, we recognize that in reality there is a range of boundary layer delay times that should be considered. Thus the significant observation here is that a relatively broad band of oscillation frequencies is expected as opposed to a very sharp peak at the center frequency corresponding to L. 2 .

In our studies the response of the boundary layer to the changes in the mass flux is accounted for by simply inserting time delays in the heat-flux expressions derived under the assumption of quasi-steady response. The implementation of this idea in the linearized version of Eq. 3 yiclds

$$
\bar{Q}_{1}(\bar{t})=\sigma_{2} \bar{G}_{1}\left(\bar{t}-\bar{\tau}_{B I 1}\right)-\sigma_{1} R_{1}\left(\bar{t}-\bar{\tau}_{B I 2}\right)
$$

where

$$
\begin{aligned}
& \bar{i}=t / \tau_{d l}, \bar{\tau}_{b l 1}=\tau_{b l l} / \tau_{d l}, \quad \bar{\tau}_{b / 2}=\tau_{b l 2} / \tau_{t I} \\
& \sigma_{1}=\left(E_{L}+1\right)\left(\frac{k}{1-k}\right), \sigma_{2}=\left(E_{I-}+1\right)\left(\frac{n}{1-k}\right) \\
& \text { and } \tau_{l l}=\kappa / \dot{r}^{2} .
\end{aligned}
$$

Here $\tau_{b / 1}$ and $\tau_{b / 2}$ are the time delays experienced by the wall heat flux $\left(\dot{Q}_{c}\right)$ to the changes in the oxidizer mass flux and the regression rate, respectively. The scaling of the time delays $\tau_{b / 1}$ and $\tau_{b / 2}$ obey the general scaling law given by Eq. 4. However the $c^{\prime}$ coefficients for $\tau_{b / 1}^{-}$and $\tau_{b / 2}$ are expected to be different since each of these delays represents a different adjustment mechanism for the boundary layer. The model presented by Equation 5 is central to the analysis in that it relates the heat conduction in the solid to the boundary layer combustion.

\section{6) Thermal-Combustion (TC) Coupled System}

Now, with the use of Equation 5 the thermal lags in the solid can be coupled to the combustion transients in the boundary layer. This coupling yields the following transfer function between the oxidizer mass flux $(\hat{I}(s))$ and the regression rate $\left(\hat{R}_{1}(s)\right)$ and represent the Hybrid Combustion block in the overall transient model (Figure 2).

$$
F_{T C}(s)=\frac{\hat{R}_{1}(s)}{\hat{I}(s)}=\frac{2 E_{E_{a}} \sigma_{2} e^{-\bar{t}_{b 1} s} s}{(1+\sqrt{1+4 s})\left(s+E_{E_{a}}\right)-2 E_{E_{a}}+2 E_{E_{a}} s\left(E_{L}+\sigma_{1} e^{-\bar{t}_{3 / 2} s}\right)}
$$

This iransfer function (TC coupled system) that represcnts the combustion phenomenon includes the dynanics of the themal processes in the solid and approximates the combustion dynamics in the turbulent boundary layer of the rocket motor. Equation $6 \mathrm{can}$ be used

5 
to investigate the stabitity character of the TC coupled system. The coinmonly used method is to map the poles of the tresfer fouction in thes phace. Particularly, the ral componacen of a certain pole of a transer function indictes applificanion

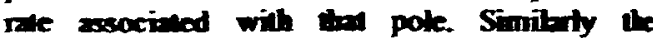

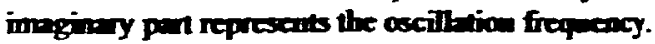

Firs a syseon with zero boundary byer dedays (ie $T_{M 1}=T_{\mu 2}=0$ is decrmined to be atways stable. $b$ fact plat of the traster fenction for a sysecs with sypical pereners stows wo poles in the s plane (only a zoco in $(0,0)$ ) inticatiog no sign of instbitity (ie. Soe Figure 3) If a positive detyy is incodeced between the regrasoin race and wall bea fhe, a scries of astuble poles is generned The con pile cuse with a 38 move dely is shown in Figare 4. Nole the all the ober poranckess are keph idesical to the case with wo detays Even though there cxises a iffrite saies of poles generated (t) the sene mippification $r$ te) we will only concentire on the pole with the lowese froquency (funderiectiol mode). We befieve then the bigher order nodes ane an atifact of wing a simple detay indead of the foll dy aics for the

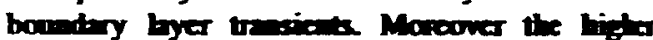
frequancy modes, even if toy exisd in a real system, are Fity to be dapped more effectivety

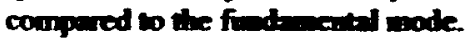

$h$ is iportat to idarify the acoesony conditions that mat eive for the gemention of TC

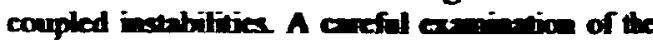

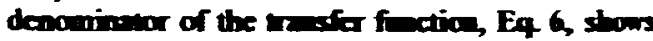

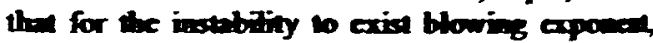
, activation cnerby, $E_{a}$ and dety tine, $T_{W Z}$ mous be nowere This indicenes then the insobify is a resol of the compling of thee physical phenomena: blocting of bect trasefer by ratiol injection of foct wases thened tresicats is the solid and bousdry byo dymanics The pos phasectsolid phese conplises mecheniem caplened by the TC conpled moded is shom in Figure 1 .

Next we comsider the effect of vaius parneses of the TC conplad inditity. It ca be

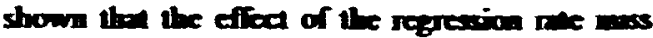
fhe exponent $n$, hed of vaporitation of the fed, $L_{r}$, the hea capacity of the solid foel, $C$, and the surface vemperatich $r_{s}$, on the oscilltion fropuency and aplitude ace negligible for the range of these paraneters that are coumonly foud in bybrid systems Also TC coupled system characteristics are completely independent of the sotid dansity, $\rho_{f}$ and the hea diffusivity in the solid, $x$.

The efied of the activation energy on the amplificaion and fiequency is shown in Fyzore 5 for $\tau_{M R}=38$ milliseconds and $k=0.68$. As indicat by the fogre, for activation oncjies commonly observed ic bybrids, renging from 5 kcalmole to $60 \mathrm{kcal} / \mathrm{mole}$, the varintion in the oscillition frequency is retaively small. The amplifiction increses with incressing activation conergy. For this specific case the systems with activation excrgies brea than 3 keal/mole show positive applifection ande belevior. Docrosed strility at higher activation cacrios is expectad since at high $E_{a}$ values the serfice lemperature and regression rate are mane closely coupled. This corpting is ane of the necessery ingredients for the gardion of the instabilities in fad in the extreme cose of $E_{a}=0$, for which the surface temperature is completely independem of the requession rate, oscilltion frequency goes 10 infimity and the aplification goes to ecgative infinity.

The activation energies for the polymeric systems that are typically used in bybrids ranges from 10 kol/mole to 60 keallmole. For the noppolymerix prafíl-bed foel system the activation cocrsy is oquivalen to the been heat of veparion ion". This value for the perfifin-bused fred formations is estimed to be 17 kealmole (Rer. 13)

Siniter ranks on be obenined for the effect of the blocting exponem, as shown in Figare 6 for $\tau_{H 2}=0.38$ and $E_{c}=15 \mathrm{kca} / \mathrm{mole}$. For the rage of values ropared in the fiecrome for $t$ (i.e. $0.680 .77^{159}$, the effeat of blowing exposent on the fropuency is negligite. The mplification increases with increasing $k$ and systems with $k$ values 0.45 and bger stonved astoble behovior. Nowe the tor the physicolly arrealionble case of $k=0$ the intebility disppers, since one of the

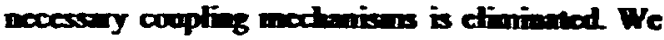
finaly fite to note the even thongt the blocking efiect in parafin besed systems is somewhed reduced due wo the two phese charicter of the flow field, its is still significan coongl to cothlish the coupling between the gos phese and satid phese.

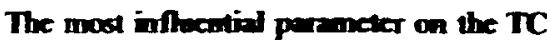
coupled frequancy is deteminined to be the boundary detay time, $T_{W Z}$ - Figure 7 shows the 
predicted froquency as function of the delay time for three activation energy values, $E_{a}=5,15$ and 50 kal/mole As shown in the figme, the cfitod of the activation conery on the frequescy, espoci-lly 7 longer deby tinges, is smoll. For the paposes of this piper the efiects of activation coctis and blowing coposent will be goored and the fropuency will be represented 25 a function of the boundary delyy time alone. The following curve fin

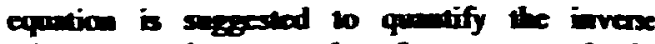
reluindip between the froperey and the bountary byer delay tione.

$$
f=\frac{0.48}{r_{w 2}}
$$

As shown in Figare 7, this expression represents the predicted frepmency to a vary hid degree of accuracy and will be used for all the bybrid systems then will be discused ber in this peper.

\section{7) Gas Dyanic Merde}

fo the previoas section be dymanic models for the thermal bes and the lightrid combustion are smandioed in alfiom, thase snboystem models ane conplod to obtim the

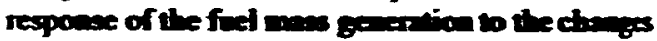
in the was fin in the por However, pactiontly significan perineters of the rocted opertion sed as the chember prosine, spocific inploc ad thrust cannot be abrined soldy from the TC coupled system. Thase vaibbles on only be determined after imoducing a moded for the ps dymanics which will be fiscussed in this section A gas dynomic model, in goand strould use the oxidion mas fow rece and the fod mos gencration rese as the ippos and it should yicld the paranders that are more clocely rated so the peformance of the motar sect 8 the chanber prosure and the motor Of ratio as the odipues.

h or spocific model (2V-port model) we

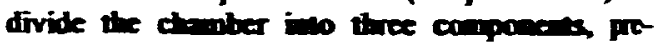
combstion cheriber, port valume and the pout conbution chanber (ie. soc Figre 8). We tren the pre and post combustion chnobers as 2000 dimessiond volume elements, ba cossider the varition of stec variables along the axis of the port. The mathemenical formultion is obuined afler the application of the conservation lows for the thee voluac elements. The sel of opritios resembling our model is solved abyically after lincriontion and as a resolh of then operation, a transfer function for the gas dynamic subsystem is obtrinad. Some minerical simulations are akso perfomed to detengiac the valifity of the approxinorions used in the parubetion solutions Noer thet a detriled deseription of the ges dynemic moded is gives in the Appendex of this poper.

The following conchasions on be dawn from the resals of the gas dyw mic moded as given in detail in the Appendix of this peper and in more detail in Ref. 13.

- Ges dymic moded captires the fillog/cuptying byonics an abo the brigitudien aconstic rasposse of the bybrid combustion cheriter. As on be seen from Figme 13 acomstic modes are stable (well dauped). No uestable oscilt tios modes ar gencrated by the gas dymamic system by isetf.

- The noatineer dstumberes excive the chonber acoustic modes Sindotions stromed tha a

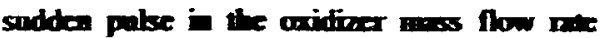
encites the soonties moda These modes decay in a retuively stort period This riaging phenomonos stows the bengindion acoustic modes can be driven by nonfineer low froquency oscithetions Nonety the nonfinea low frequency prestire waveforms cominowity caice the acontic modes of the chomber. AMROC notor DM-01 stowed at

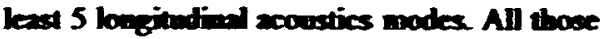
were well denped The ges dymoinic moded when corrected for isentropic speed of somid prodicts the acousties frequencies of the DM01 moter to a bigh level of accuracy (See Table 7).

- Ces dymaic anded coupled will be boundary byer dyenices $\left(\tau_{M} \neq 0\right)$ does not produce any instabititios (no extre poles are genered in the $s$ phine). This conchusion is besed on uraster finction andysis and also

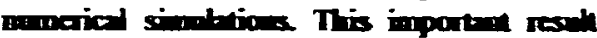
hightights the iportace of the thermal bs sysecon (i.e and is mique dyemic capabifity of producing a pluse lead) in producing a coupring mectanisen to poraric bo fropuency nuste modes.

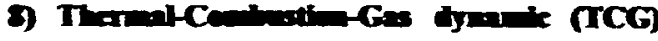

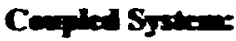

h this section we infograte the gas dymonic sysiem to the TC couplad system to establish the TCG conpled rosponse (ie. See Figure 2). The TCG coupled system yields the performance of the rocket (such as chamber

7 
pressure) for some given input of oxidizer mass flow rate, which is a fuodaniental control parameter in hybrid rockets. It is fair to state that the TCG compled sysem represents the most fundamentad dyanoic behovior of a bybrid rocket

The schenatic of the bybrid sedoysters and the iaformmion flow between the seloystems in the contex of TCG coupfing are shown in Figure 2 Nole the the lower block in the scherm tic ropresents the TC coupled syster. The ingue for the TC conpled system is the local ins fox information and the oupat is the mas generation of the regresion rice $\mathrm{T}$ e epper bloct shows the 2V-pon ges dywaic modd. The ges dymanic model toles the cexidiver flow rate and the mass generation rate information and reveals the importane performance porameders sach is the chamber presoure and specific impulse The TCG coupled system can be considered as an overill moded for the dymatics of a bytuid propation

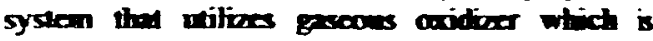
detivered by an isolated food systen.

The genarification of the TCG conplad systam to a Fipid hybrid with sigificon food system dywanies can be achievad eaxity. Nandy two more modales for the Equid dopia evaporation and the feed system dyremies mind be added to the from end of the TOC moid We beticve thet the fundenentel phoomenes generating the low fropucacy intarities of bybid systems does en iavolve cinter of the eveporation begs or the feed system dyomics.

In the TCG coupted system the gus dynamic module converts the fod mass oscillitions produced by the TC coupled syseem in the chamber pressure acillitions $h$ has been determined thet in the process of oometion, the oscillations prodoced by the TC cophed systen (i.e. froquencies and amplification rmes) are nol alkerod. This fact is demonstrand in Figre 9, which shows a plot of the TCG systes irmoter function for the TC couplod systern depicted in Figure 4. The sane plot also interes poles associnted with the filing/enptying ode (firt

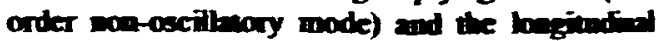
acoustic modes with negative real componons (dimped). TCG coupled systom captures all the necessery undertying dynesnics (fine ined vasion) of a gascous hybid with a deconpled food sysecm.
9) NASA Amses Parafin-Based Moter Tests:

A promising fast burning paraffin-based fucl bes bees usied extensively in the Hybrid Combetion Facitity (HCF) at NASA Ames?. The molor outside divencte is 10 inches and grocoes oxygon is the oxifioer for all the lests contuxted at the HCF. The prosere time trece of a typical perrfin-based hybrid moker lest is shown in Figne 10, whereas the Fo ier toraform for the seme tat is gives in Figore 11. Nate the the cheraber prosere troces for ctasinal hybrids as presented in

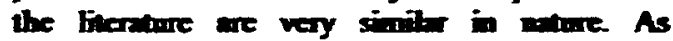
indicaled in Figure 10 for a particular cose, the foed system and the dre-iber ware completely decorpled for all porffimbesed motor tasts vesed in this peper.

Ne Forier trasfong shows the brond peaks comesponding to the low fropococy bybrid instubitity, the Hebnitro mode and the firs longindinal mode. $h$ bes been generally observed the the douin al mode, bow frequercy oscillations are acompanied by lowe anplitude higher frequancy scostic modes. See Ref 6 fo exensive discossion of the stobility chancteritics of the purdifin-bed worors.

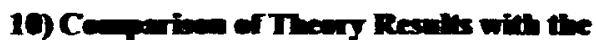
Moter Test Din

In this section we will compare the TC couplod theory oscillation frequency predictions with the chrober pressere oscill-ion firepnencies from lybrid molor las dita ba onder to produce a conchusive conporion, we hre selactad a bre number of loses form several hybrid rocke developmant programs. The key features of each progerem is discussed briefly in the following pargraphe.

- AMROC Motor Teses/13: b this cose the reported resols are for 4 differen thras cless hybrid mows which all nilined LOXKGOX as the oxidizer and HTB as the foel. The dat from the AMROC vests is given in Table 2

- HrDP 11 led Molor Testss: The coidied used in these last is LOX and COX and the fued is HTPR/Escores formbetion The molor cose diancter wos 11 inches and the dita from 5 vats used in this sendy is given in Table 3. Only the tosts the cxhiti combestion instability and performed with single por molors ane considered. The rums with the rarwart- Exing steps at the port cotrance are ako crchuded i this stady, since in these tests 
the flow field in the port is significantly altered which my cause a mojor change in the boundy byer detay time coefficient. We abo include lest Al of 11 inch LOX moler don in the arilysis. We only consider lasa 1 since it is the caly nu with a chubue configarion identical to GOX wotors esed in the colcubions

- MRAD Molor Tass ${ }^{1321}$ : The oxidien used in these lase is COX and the foel is

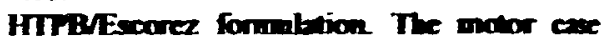
demacer wos 11 inches and the date from 8 lests usod ia this stedy is given in Table 4. Only the tests the exhiti conbetion inembifity an perforned with single por motors are cowidered bere.

- Arizone Stre University" One lest is incladed is the comporivon for a 5 inch dimineter nitrous oxide motor. The fuel wos HTPB (ie. Sec Table 5).

- Paraffin-Based Motor Tesas": These lests ane conduciad a NASA Ame in a 10 inch dienveler los fecility. The oxidiace was GOX and the fuel is two seperencenpolyweric parffin-based formations (SP-1a and SP-4) The don form 25 molor tosts are reported in Trable 6.

The prediction of the frequency requires

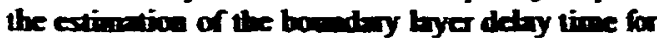
cach wat from the roported don Since the roported dae is somewhe difforen for each progren difioun scaling birs for the detry tine must be derived.

The firs one of those is for the various size AMROC molors which operaed a differen $\dot{L}$ levek. Since the information on the AMROC motors the can be found in the liverniare is hivited to $L^{*}, c^{*}$ and mowor OF raia, is is desirnble to express the boundary byer delyy tine, Equation 4 (with $z=L / 2$ ) i cams of those variables The average velocity in the pon con be ppracinated as

$$
w_{m e}=\frac{G,(1+2 O / F)(1+O / F)^{\prime}, T_{-}}{2 P_{c}}
$$

where $K T_{\text {ore }}$ is an avernge value in the port. Substituting this cyression in the dely formath and wing the retwions for the loted mass flow rile $\dot{m}_{i}=G_{1} A_{p}$ and port volume $V_{p}=L A_{p}$ yiclds

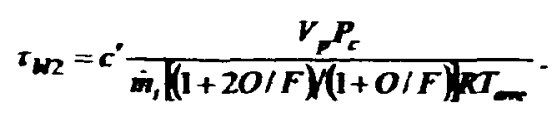

With the use of the total mass flow relation, $\dot{m}_{b}=P_{c} A_{-} / c_{\infty}^{*}$ and the defusion $L^{*}=V_{a} / A_{m}$. the delay oquivion con be writien as

$$
\left.\tau_{W 2}=c^{\prime} \frac{V_{p}(1+O / F)(1+20 / F)}{V_{E}}\right)_{i} c_{\infty}
$$

Here $V_{n} / P_{2}$ is the ratio of the part

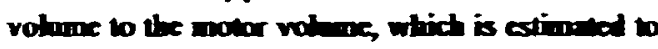
be approxicuely 0.8 for AMROC DM-01 motor. We asuine the all AMROC moturs posecss the saine avarge gos conster temporature prodect,

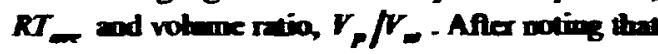
all mowars operace a vary sinil onf ratios ad $c_{0 \text { p }}$ vatues, i can be sted thet in the sories of

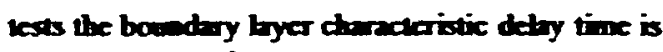
proponticanal to $L^{\circ}$.

In onder wo reduce dota form the rest of the vests, a simiter retaios for the boundary byer delay tine in toms of the ctomber prossore and port flux levels mast be derived The pon velocity $c m$ be reptaced by an averaze value $\left(G_{+}+G, V_{2} \rho_{\text {me }}\right.$ with $\rho_{\text {m. }}$ given by the gos bw $P_{c}=\rho_{\text {dex }} R T_{m}$ wo yicid fimally for the boudary hyer bo:

$$
\tau_{W 2}=c^{\prime} \frac{L P_{c}}{\left(G_{0}+G_{2}\right) \mathrm{R} T_{\omega}}
$$

Fquation 11 gives the scaling bar for the boundary byer dety in vams of the operating points of the rocked wotor and also with the sine of the molor. This sthes thet dety increses with increasieg chomber presiare, pon lengh and decreases with increasing mess fin in the port An importin conchacion the con be drawn from those observations is then ancrease in the chamber prescice or a docrese in the port mass flux act to docrease the oscillnion fropaency of this type of TC coupled system

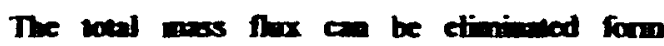
Equation 11 by introd cing the arorage oxidiaer to facl ratio of the molar.

$$
\tau_{b / 2}=c^{\prime} \frac{L P_{c}}{\left(2+\frac{1}{O / F}\right) G_{\sigma} R T_{-}}
$$

Equation 12 will be med to raduce the parafile besed movor dan

9 
Note that equations 10,11 and 12 are cquivalex ad the constand mentiplier $c^{\prime}$ is identical for all of these copsessions.

The avange temperature gss const product thet appers in the denomineta of all the

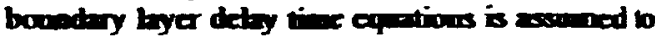

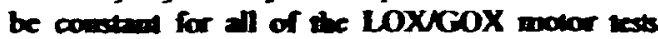
tha is considered in pepo. This is a Eity good semption since $\boldsymbol{K T}$ is a wet funtion of the mow orf for the prectical oporing conditions". In fact the moriman expected variation on the $R T$ values for all the LOX/COX vests wed for conprioce is predicted to be less then 5\% The abohere value of $R T_{\text {are }}$ is setected to be $6.3910^{5}(\mathrm{~m} / \mathrm{sec})^{7}$ for LOX/GOX mowar tests and since the sune value is wed for all caloultions

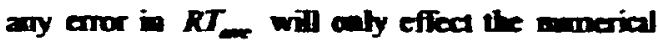
value of the empirical detoy constam $c^{\prime}$.

In orida to dable cheot the $R T_{\text {- }}$ value used in the calcalitions one could use the find acoustic fropuency messiced form the molor tad data and use that io atinge the speed of sond and frally $R T$, based on the following oquation.
Here $\gamma$ is the ratio of the specific heats averaged over the lengh of the movor, $f_{1-L}$ is the firs bonfitudinal nooustic mode ad $L_{m}$ is the cfiective kength of the molor. For a wore accare calcutation the complax ges dywaic moded disenssed in the Appendix of this peper con be used. Al of the NASA Ames moler lests with 45 inch hang gries bed thei fins acoutic mode a around $370 \mathrm{~Hz}$. For these lests with ese of $y=125$ and $L_{m}=1.27 \mathrm{~m}$, one oblesins $R T_{-}$of $7.110^{5}$ (molsec) $)^{2}$ wich is aly $10 \%$ higher the the assomed value $K_{\text {or }}$ for the $\mathrm{N}_{2} \mathrm{O}$ test is selected to be $5.110^{5}(\mathrm{~m} / \mathrm{sec})^{2}$. This is $20 \%$ boner then the

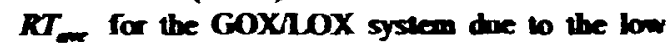
comperature of the N2Ohydrocarbon combetion products.

Now Equation 7 can be coupled with the exprestions for the bonadary delays time to evaluese the frequeacies predicted by the TC couplad model.

$$
f_{1-1}=\frac{\sqrt{r R T_{-2}}}{2 L_{n}}
$$

$$
\begin{aligned}
& f=0.48 \frac{R T_{-c}}{c^{\prime}\left(V_{P} / V_{-}\right)[(1+O / F)(1+2 O / F)] L^{*} c_{c \phi}^{\circ}} \\
& f=0.48 \frac{\left(G_{c}+G_{b}\right) T_{-}}{c^{\prime} I P_{c}}=0.48\left(2+\frac{1}{O / F}\right) \frac{G_{\sigma} R T_{-}}{c^{\prime} L P_{c}}
\end{aligned}
$$

The cocillition frequacy as a fuction of the boutery dely tiane predicted by the TC

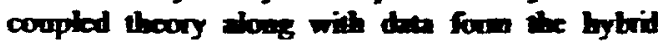
motor developmen prograns ane plowed in Figue 12 Nole the we bive used a boundry byer dety coostan value, $c^{\prime}$, of 2.01 for all woor easti order to obth the beat fit between the theory an

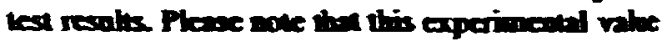
for $c^{\prime}$ is the soinc onder of arg gilade with the rough estimate (i.e. -0.55) for a bondty byer with no blowing and no combustion.

Considering the wide renge of ret conaditions, the agroment between the measured presere oscillution froquencies and the TC couplad moded prodictions is suprisingly good Note thet the comperison inctedes 43 mom lests

- Using resals from 4 diffucm development and resench programs

- Usiog 3 sepurte oxidivers (ie LOX, $\mathrm{COX}$ and $\mathrm{N}_{2} \mathrm{O}$ )

- Covariag a wide roge of molor dinensions (ie. from 5 OD Arimen stac molor up to 72 OD AMROC motor)

- Using mory fifferem fuel coupositions (i.e. HTPB, HTPBESCOREZ, HTPBDDUESCOREZ, 2 perifin-bed formalations) 
- Covering a wide range of operating conditions.

Equation 14 a indicates then for motars operating at the similar $O / F$, the oscillations froquency is imversely proportional to the $L^{*}$ of the Inotar. This conctesion is consisted with the previons resulus reported in the ticenawe. Simitary Equation 14b shows for movor opereing a equal oxidied wass fluxea, dumber presseres and OfF the oocillution froponcy decreases with increasing

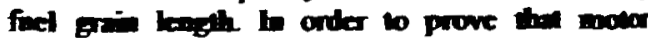
length plays a critical role setting the oscilbtion frapucacy, we herve ploned the Ames mowor den, which comins two sets of grais lengthes by renowing the leagth efiod from the sching bw. This realled i : increase in the scuer in the frequacy dat indicating the inportunce of the

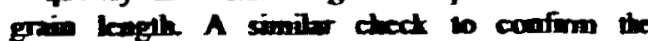
importance of langth can be conducted by comparing the JRAD and HPDP notor lests (ie ron with grains 102 inches long) with the Ames peraffe keses (i.e. ran with grains 32 or 45 inches long) the were conducted under very simite

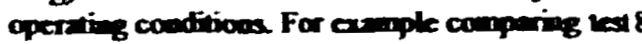

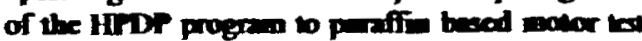

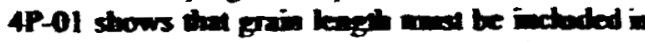
the scaing bu in onder to equic the discrepery in the oscilintion frequecies for these tots $\mathrm{n}$

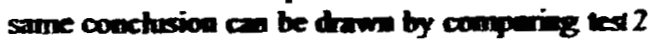
of HPDP progerm to the test Anes 4LCOB.

TC capled theory prodicts oscillenions of

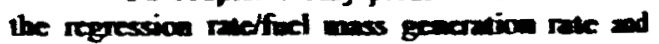
wosld be observed dicealy in a lybirid molor as the raifal oscillations of the difficsion flane withis the boundery byer. The gas dywomic model comers

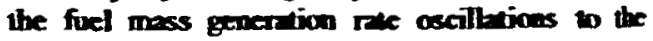
chamber prosoure oscilmions. It is expected thet a system operating a bigher of inios wond

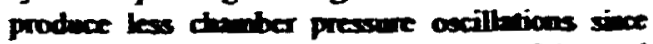
fuel moss constinde a sinalle fraction of the wat mose expelled for tive moele. This fat is obscrved in NASA Ames molor leste, naphety bigh

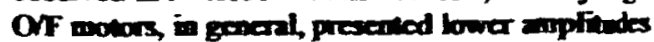
chamber prosine oscilltions conpered to the men chamber prosore.

The simple fiocor model presecoud in this peper seccessfully explais the gencration of stoll amplinude bon frequency oscillinions and the scaling of the fropuconcy. But in atso fibety prodicts an indefinite growth of ctumber prasere oscillations. In reality, the noalinear unechanisms the axist in a hybrid motor would timin the indefinite growth of the oscilbutions and resul in limit cycle oscillations that are commonty observed in motor lests. Moroover the simple theory does not explain when these low frequency instabilities will take place and whan theis amplitudes would be. it has been shown in the hybrid development prograns thet the fore and configarationtuolane of the molor plays a poramount impartance in setting the amplitude of the bow frequency instabilitios. The moter tests indicated that, at least for grsoous motors, axiol injoctors resulh in more stoble opertion compored bo the radiel or conical injection of the aidiona.

A word explanion for these observitions is the the TC coepied inctibity mochanism almod ahorys exist in hybrid systems, bet the amplitude of the finil cycle oscillations will depend on the excivition level by the disturberses in the righa fropucacy rage. We believe that the fore and fluid dy mins (ive vonex shedding) is

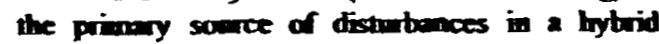
roctal For comple chonging the injection schene of the oxidioer from axid wo radial, ony introduce a flow disublence componem teat is preferred by the TC cospled systen If coe ascomes the all the bow frequency oectlations ane developed by the Thid mochenies $n$ the fore end of the molor, one wonld fil to explain the lengh effec on the oscillation frequery. Also all oxidiser ijection schemes ode idemich now operatios condivions sean in produce the sane oscilbation frequency. This Ead is also difican to explain by the assumptions the all the oscillations are produced from the fhid dymaric eveats $z$ the fore cod of the molor, since the injection scheme showld alver the fhid mechemies sigmificanty (i.e. vorkex shedting froquency)

We would Fie to nok that mose of mesical instruments atso work on the some principlez. For exasple in a floc organ pipe the cohmon of in iuside the pipe is sel ine vibration (i.e. a its potiral froquencies) by an edge wane which is prodeced by a jet of air then inpinges on a crefully desiged Fp. The vorta sholding at the bip sets the edge wone which isedf excies the naturel modes in the pipe Nove then in the cose of an orgen pipe the jat speed and the bp geometry is carefully selected for the pipe langh sach the the edge lone protuced at the Ip contrins a bo componen $a$ the and frequency of the pipe the nocts of be excied In wis orga pipe malog the lip is the fore cod of the motor (ice grometry, injection schene, velocity ac) and the argen pipe is the hytrid system modeled by the TC coopled theory.

11

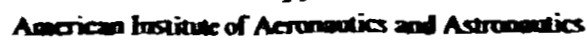


11) Conchasions:

The following conclusions can be drawn from the results of the TCG coupled model:

- A pbasible mectunison that gonaries lomfrequency chamber pressure oscillations is sugesed. This mechanisen is doe 10 the coupling of the thermal lags, the gas phase combution and gos dyminic sub-systems of the hybrid rocket. The physical transient model of the mover is presented in a mathematical formalism that allows one to exime the expected occilletion frec sency. The amplitude of the oscillations can not be determined by this fine model.

- The oscillation frequency estimated by the model is in vary good goreement with the motor test data from several programs utilizing three futina oxidioers sevaral fuel formatations a wide rooge of molor dimensioss and opering conditions We sugeast the following cqunion as a wiversal scaling bw for the pringy bybrid oscillition fiopuency:

$$
f=0.239\left(2+\frac{1}{O / F}\right) \frac{G_{g} R T_{T}}{L P_{c}}
$$

$R T_{-}=63910^{5}(\mathrm{abec})^{2}$ for COXMOX sysiens

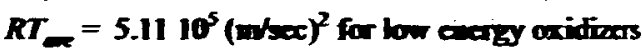
systems such as $\mathrm{N}_{2} \mathrm{O}$

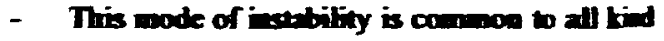
of bybrids: Eypecfyios or conventioned fects, Fquid oxidion or gascous acidiocers. $h$ is rasonable to betieve thet this low frequency mode is presen in every hybrid system to some codere Sane molors are more nowble compered to the oflas becrese these wotars

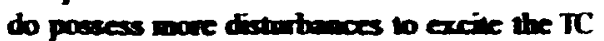

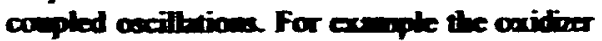
injoctor configurition or proconbestion chanber geconctry affects the scale and the

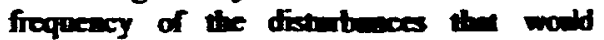
excite the comononty observed bon fropseary mode. For this reson the desige of the fore and of the mow hor bee critical in controlting the stobitity of the system.

- Even thoegr the liner heory vey saccassielly predicts the oseiltation fropuency of the chamber prassure, if frils to estublish a estimntion process for the anplinade of the oscilbations. The theory predicts in unfimited growth of the oscillations. In reality the anplitude of the chamber presure fucturations will be limited by nonlinear effects that are not covered in the finearized TC coupled theary.

- It has been shown that the longitudinal acoustic oscillations that are commonly coexist with the low frequency oscillations can be gencrated by the excitation induced by the nonlinear waveforms of the low frequency chamber distubences in short, in is plasible that high frequency acoustic modes are driven by the low frequesecy oscillations.

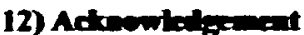

Part of this work was carried out under cooperative agreements NAG3-2615 with the NASA Glenn Research Center and agreement NCC2-1172 and NCC 2-1300 with the NASA Ames Research Center. This work was also supported by NASA grant NAG3-2884.

\section{3) Referoces}

1. M. W, Beckscead and E W. Price, "Nonecoestic Combustion Instubility", AlAA Jound Vol. 5, Na 11 p. 1989, 1967.

2. R. S. Browe ad R. J. Muray, 4linem and Nontince Presenre Conpled bostabitity of Solid Propellunts', AlAA Jourmel, p 1492, 1970.

3. F. E. C. Culict and V. Yang, "Conbestion funobitities in Liquid Roctets", Prograss in Astronentics and Acromentics, Vol.169, pp 3-37, 1995.

4. D. M. Gullic and R S. Wolf, cNoar Acoustic Conbustion lestebility in Hybrid Rocke Molors", N 91-24250, 1991.

5. T. A. Bondur a, R. L. Componica and S. E Clafin, "A Comperative stidy of the Effects of Liquid-Versers Gaseous-Oxygen bijection on Combustion Stabitity in 11-inde-Dineter Hybrid Molors", AIAA per No97-2936.

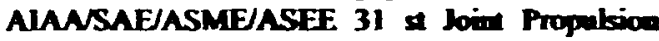
Confarence and Exhiti, haly 1997.

6. Shanc De Zitwa M Arif Krabegoghte and Grag Zilliac, "Combstion Oscillations in High Regression Rate Hybrid Roctets", AlAA poper 2003-4465, Join Propolsion Conference, Hentsvilld Albuem, 2003.

7. B. Graina ad R A Frodaicht, Experimental imvatigation of Lubscale Hytrid Instability", ALAA paper, No 94-2878, 1994.

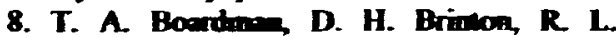
Carperiter, T. F. Zolods, An Experimemal Investigation of Pressure Oscillations and Their Suppression in Subscale Hybrid Roctet Motors", AIAA peper 95-2689, 1995. 
9. R. M. Jenkins, J. R. Cook, "A Preliminary Amalysis of Low Frequency Prossure Oscilletions in Hybrid Rocket Motors", AlAA paper No. 95 . 2690, 1995.

10. B. Greiner and R. A. Frederick,Jr, "Hybrid Rocke Inst-bility", AlAA peper, No. 93-2553, 1993.

11. C. Wooldridge, G. A. Marmon and R. Kier, "Investigation of Combustion Instability in Hybrid Rockets", NASA CR-66812 Final Report, 1969.

12. C. Wooldidge and G. A. Mrrmas "Combustion Instability and the Role of Chemical Kinetics in Fybrid Combustion" AIAA Jomm No. 68-498, 1968.

13. Karbegroge M A "Trasien Combustion in Hybrid Rockets", Stanford University Ph.D. thesis, Angur 1998.

14. Karabeyoghu, M. A. and Alman, D. "Dynaric Modeling of Hybrid Rocket Combustion", AlAA Journal of Propulsion and Power Vol. 15, No 4, 1999, p. 562-571.

15. Marxman G. A., C. E. Wooktridge and R. J. Mnexy. "Fundamconals of Hybrid Bowalary layer Combustion", Progress in Astronmutics and Aeronation, Vol.15, 1964, p. 485-522.

16. Parikh, P. G., Jayaraman, R, Reynolds, W. C. and Carr L W, Tr sie Resposse of a Turbulent Boundery Layer" FED-Vol 12, ASME, New York, 1984, p. 31.

17. Schlichting H, "Boundary Layer Theory", MeGraw Hill, Chplea 21, 1955.

18. Moelwyn-Hughes, E.A., "Physical Chemistry", Chopher 6, Second Revised Edition, Pergamon Press, 1961

19. Atman, D. ad Hiable, R. Hybrid Racted Propolsion Systems" in Space Propulsion Analysis and Dasign, McGraw Hall, 1995, p382

20. M. A. Karbeyogh, Greg Zillix, Brian I. Cantwell, Shome Detilu and Pal Croditaci "Scalemp Teats of High Regrasion Re Liquefying Hybid Rocke Fuds", AlMA-2018-

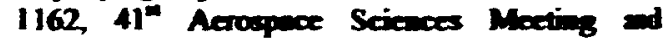
Exhitis, Reo Nevade, basady 20103.

21. T. A Bourlene, R. L Capener, B. E Coldberg, and C. W. Strefier, "Developmen and Teating of 11- and 24 lnch Hybrid Moros Uter

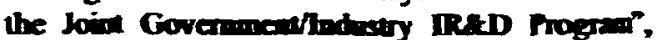
AlMA Paper Number 93-2552, AIANSAEI ASME/ASEE 29 th boin Proplsion Confaraxe and Erhiti, hose 1993.

22 J. M. Praci, The Effects of Swil hijotor Desige on Hytrid Fbone-Holfing Combestion Instabifity", AlAA Paper No. 2002-3578, AIAASAEJASME/ASEE 38h Joint Tropolion Couference and Exhibit, July 2002 .
23. Jeans, James, "Science and Music", Dover Publications hic, New York, 1968.

24. L. Crocco and S. 1. Cheng, "Theory of Combustion Instabifity in Liquid Propellent Rocke Motors", Agardograph No. 8, 1956.

25. H. Lomax and T. Palliam Finite Difference Methods for Fhuid Dynamics", 1993.

\section{4) Appendix}

In our gas dynamic model the motor is dividad into four subsections: 1) pro-combustion chamber, 2) port volume, 3) post-combustion chamber, 4) noeste. Exch conponem is approximated appropriately with one or zero spatial dimensional modek The subscripts 1 and 2 are used for the physical properties in the pre and pose combustion chambers respectively. Vajous stations of significance are also distingurished by use of sobscript notation. Namely the cmtrence station of the gaseous oxjdizer into the system is represented by a subscript $\mathrm{a}$, the nowede cutrance is denoted by $n$ and the pon entrance and exit are shown by a and b, ropectively. Our models for these subsections are discussed in the next section.

\section{Pre-Combustion Chamber}

We use a zero dimensional gas dynamic model for the pre-combustion chamber. Thus the momentum equation and the energy equations reduce to the mean state informution of the pressure and temperature in this volume. But, the mass babance equation is nontrivial and it $\mathrm{cos}$ be written as

$$
v_{1} \frac{d \rho_{1}}{d}=\dot{m}_{-}-\dot{m}_{0}
$$

Nowe the size of the volume is assuried to be constan over the ben time. We furthe astine a constan moles usos and a polytropic process, $P \propto P^{n}$, in the chanber. Here $n$, is the polytrapic exposent We believe tha these are reasomble asemptions for this relativety cold volune which acomonodes nogligible combustion Under these stued conditions ad wilh the we of the ideal ges $\mathrm{kW}$, cquation A.I can be reduced to

$$
a_{1} \frac{d P_{1}}{d}=\dot{m}_{0}-\dot{m}_{a} \text { where } \quad a_{1}=\frac{V_{1}}{n_{P} R_{1} T_{1}}
$$




\section{Port Chamber}

In our model we treat the port as a quasjID tube with continuous mass and bea addition The conservation of mass can be written as the following difierentiol oq ation.

$$
\frac{\partial \rho}{\partial t}=-\frac{\partial G}{\partial z}+\bar{m}_{f}
$$

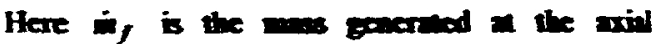
location $z$ of the port. At this stoge we pefer to express the wass generdion ten in the generd functionel form

$$
\dot{m}_{f}=\boldsymbol{N}(G, z)
$$

The monentim equation in the port cas be writion in tams of the local meses flux, $G$, the bol prosure, $P$ and the bocal donity, $\rho$.

$$
\frac{\partial G}{\partial t}=-\frac{\partial\left(G^{2} / \rho\right)}{\partial \tau}-\frac{\partial P}{\partial \tau}-\left(\frac{C_{,} C}{2 A_{P}}\right) \frac{G^{2}}{\rho}(A .4)
$$

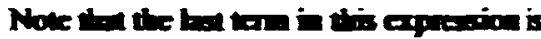

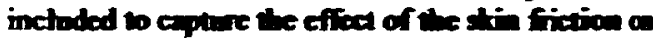
the force balbace. Hexe $C_{f}$ is for the sin friction coeficicion a bocion $z, A_{\text {, }}$ as the pon area and the $C$ for the cicunferese of the port All the geometrical properties are ascined to be independen of time and axiel dincesion This is a reasomble epproximation for typiod lybits which

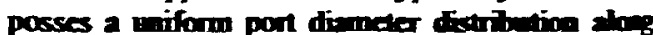
the longth and also a slow variation of the pan peomoty 15 .

We funther asoupe the the ideal gas bw bolds bacally in the port

$$
P=\boldsymbol{\mu} \boldsymbol{T}
$$

The clocure of the sysecen ropintes the cnergy oquetion. For the sole of simplicing we roplace the energy equetion with the collowing fincer varimion of vemperatare gos constat product in the por.

$$
R T(z)=(R T)_{h}+\left((R T)_{2}-(R T)_{h}\right) z / L
$$

Note that for the simplicity of notation we trea the ges coustin tonperiure product is a single dependent variable.

Furthermore we assume that the gas coustant iemperidure prodoct at the exit of the part volume is a fraction of the nozale entrance value

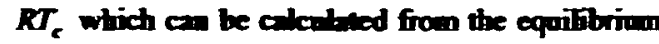
chenistry at the operatin OF ratio of the motor.

$$
\boldsymbol{R T}_{\mathbf{2}}=\boldsymbol{S}_{\boldsymbol{L}} \boldsymbol{M} \boldsymbol{T}_{c}
$$

In short, we specify the whole temperame field in the motor dherber for a given operating point and we igore the veriotions in the

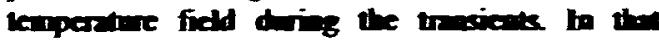
respect 2V-port is an isolbanod gas dymic nic model.

\section{Part-Combertion Chander}

Similer to the precombustion chamber

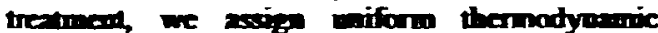
properties for the ges in the postcombestian cheriber volume. Merefore the dywanics can be represented with the mass babnce which thes the following form aflet the fred vohme assimption.

$$
v_{2} \frac{d \rho_{2}}{d}=\dot{m}_{b}-\dot{m}_{m}
$$

Here $\dot{m}$, is the mass flow ree entaing the hot volume and $\dot{m}$, is the mass fow rate exiting the volume through the noente Nole that we hive inherently assumed that post-combustion chanber behaves lite a well stined neactor with the reactions fore compared w the trasien reses of concern. Equation $\mathrm{A8} \mathrm{cm}$ be writien as

$$
a_{2} \frac{d P_{2}}{d}=\dot{m}_{b}-\dot{m}, \text { where } \sigma_{2}=\frac{V_{2}}{R T_{2}}
$$

We have sproxinged the gas consen comperaint product is the postonibustion chamber with product at the port exit

Noezle

We firs aseme then the nocade flow is quasi-steady which is only valid a vary slow transienta We also ascorite the through ont the operation of the motor, the noecte is always choked, manchy an any lime the ratio of the chamber presseure to the anbiemt pressure is brger

14 
than the critical value associated with the propertic of the copeating gas Afer these simplifying assumptions the noede how rale cra be expressed with use of the chassical quasi-ID ges dynomic fombla

$$
\dot{m}_{n}=\frac{A_{1} \Gamma_{c} P_{2}}{\sqrt{R T_{c}}}
$$

where

$\Gamma_{r}=\sqrt{r_{c}}\left(\frac{2}{r_{c}+1}\right)^{\frac{r+1}{\left.2 r_{c}-1\right)}}$

Here $\gamma_{c}$ is the ratio of the specific heds of the combustion products.

At moderne froquecucy oscillations (such as the acoustic modes of the molor), the acomsic admintwoce of the wocale meal be considerod and a more sophisticated betwivior now be modeled for our puposes, in is adegente to atph Croceco's cxpression 24 for the noede treserer finction which is valid for smoll devietions from the mon chamber prossure and for moderence fropenciea

$$
\frac{\overline{\tilde{m}}_{-}}{\widetilde{P}_{2}}=\frac{A_{1} \Gamma_{c} \tilde{P}_{2}}{\sqrt{R T_{c}}}+k \cdot \frac{d}{d}
$$

Here 1. represents the efied of inertia of the ges in the convargan partion of the nooste in casing a phese difierence between the oscilltion of the velacity and pressure at the citrance of the noeste.

$$
k_{m}=\frac{c_{*}}{r_{c}\left(f_{*}^{2}-x_{e}^{2}\right)}\left(\frac{c_{*}}{u} \frac{r_{c}-1 x}{2 c_{*}}\right)+
$$

This indegration is performod on the whole convergent portion of the noede. Note the $c_{\text {. }}$ is the critical sound velocity, " is the local gas velocity in the woodes $w_{e}$ is the gas velocity $a$ the nowale citrance.

Equations A.9 and A.11 and the ideal gas bw can be combined wo relate the pressure perturbetion directly to the mess flow rete parubation at the ein of the port

$$
\left(a_{2}+t_{n}\right) \frac{d \tilde{P}_{2}}{d}=-\left[\left(\frac{V_{2}}{\left(R T_{c}\right)^{2}}\right) \frac{d\left(R T_{c}\right)}{d}+\frac{A_{v} \Gamma_{c}}{\sqrt{R T_{c}}}\right] \widetilde{P}_{2}+\dot{\omega}_{b}
$$

Note that a fraction of the nowede voluone is added to the post-combustion chamber volume to accoum for the inertial effects of the gss in the nozzle. For typical hybrids the effective nozzle volume is small conpered to the post-combustion chomber volume. We fimally indicate then for or isothamal treativen the emperstre darivative tam is idenically zero.

Equation A.13 incledes some propertios of the combestion products which are not bown

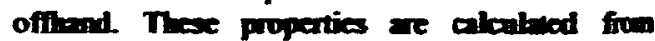
chemical equitibies considernions with we of the code STANUAN for the seleced propellow $A$ sanple calculbion resll of the product, RTC with the movor OF raio for HTPB-axyga system is given in Ref. 13.

\section{Solion Teduigues}

In this section we develop saall paturbation solutions and ako mumerical solmious for the system of equations derived for the $2 \mathrm{~V}$-pon model.

\section{Perturbation Solutions}

We desmine pertubetion solutions roond a nominal operting poind of the roctet for the ges dyounic system of equations described in

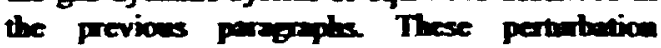
solutions will be wed wo obsice a trosefer function

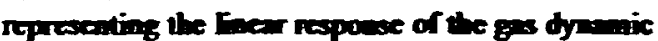
system. The trasfer function wes the aridiner mass fhow rase as the inpat and the system pressure for the ompor. The detrils of the derivation are shown in Ref. 13.

The transfar function specifically between the oxidies mass fing inpen and the pre combustion chamber pressure odpa can be writem as

15

Aocrican bestituke of Acronontics and Astrunatics 


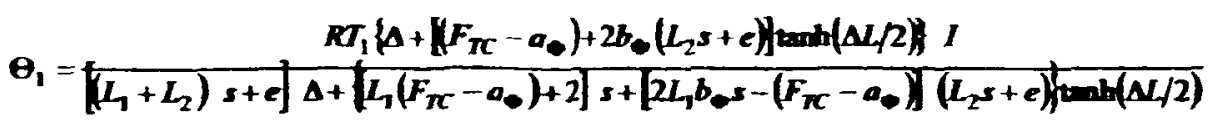

This function abo represents the overall neme of the rapose for gos dy mic systen Simiter expressions for the olter varibles $a$ be also

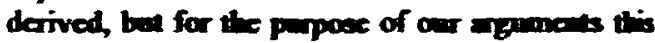
exprescion is adeque.

\section{Numerical Sramiations}

In onder to chect the validity of the assamptions used in the pertubetion solutions, we also perform ninerical simaletions on the $2 \mathrm{~V}$-put model described in the previons section. We the wilh the frite differeacing of the special daingive cerms and use the scoond order combel differencing over a uniform mesh along the aris of the port? For the tine mading we we the R. fourth order method Ine boundry condions far the port equrtions are abbind from the pre and pas conbestion chenber dyeric eqpetions The mancrical mabod wed is the calculations gre

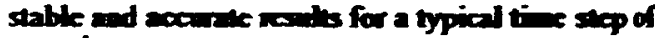
$3 \times 10^{-4}$ seconds and 80 moch poims in the port The detaik of the worerical schere is discosed in Ref 13.

The simubtion code is applied to varions transient events such as the throuting and the simusoidal axidien flow rate case. Some of the results are diecused in the following section

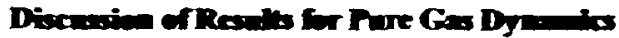

The rexposse of the ges dymic systan for a hybrid motor can be detuced from the ges dynowic system treofer finction For ox uple, the stbitity fentes of the syeen are revealed by the roots of the dena. - of of the trester fenction which is the chermatistic opanion. Homever ay investigetion of the gos dynanic system respowse requires a ingl for the combustion response then is represemed by the $F_{T}$ term.

In this section we wse the simplest quasisteady conbotion woded Nandy, all the trasien effocts inctading the thenal bos in the solid and ako the boundey bya detys except the gos dynamics ane izonored in this moded for the reson, this model which does not dilow any dymomic coupling between the sub-systems of the rocted is highly desirable to isolate the

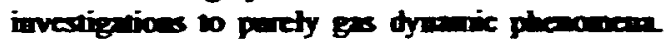
The combustion response fuction on esily be derived from the generrel regression rate bu aflar fincarication and Laplace transformation.

$$
F_{T}=a_{1} m \bar{G}^{-1}
$$

For the case of the quasistenty combustion the gs dyneric system transfer function is plotiod in Figure 13. The opertional porencers of this mon are discossed in Ref 13. The plot soms a pole on the negative real aris and a row of inogiary poles abo if the megative red half ptre. The real pole resembles the volumetric capacity of the chamber, whereas the imaginary poles ropresem the boigitudinad acoustic neture of the covity. Note thet all the poles brve negive real parta nemety the both acoustic and atso the global response components docay in tinic. The conctesion is then the pre gas dyeanic system is stable in andure.

fo order to teat the validity of the trasser function we consider the trivial cose of wo nis adfition and no vemporature or velocity grafients in the pon $b$ this case the tresser function siapifies to

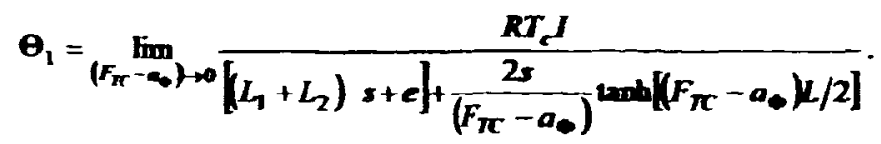


After the application of the L'Hospital's rule one obtains the well known transfer function for a simple single volume system.

$$
\theta_{1}=\frac{R T_{2} I}{\left(L_{1}+L_{2}+L\right) s+e}=\frac{\left(R T_{c} / \theta c^{*}\right)}{\tau_{f} s+1}
$$

Here $\tau_{f}=L^{*} / c^{*}$ is the chrexceristic filling tione of the molor cherber. The olled prenctus are defined \& $L^{*}=V / A_{p}$ ad $c^{*}=\Gamma_{c} \sqrt{\pi_{c}}$ with

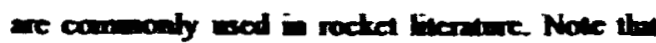

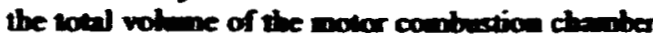
can be written as $V=\left(L_{1}+L_{2}+L\right) M_{2}$. This is the urasta function ganorally used (appecially in te industry) in bybrid dymoric modeting
The preceding equetion bes not predict the filling/emptying time scale of a hybrid rocket acurately. For the resoon we develop a bener estinue by the following agrene in the region of the 3 plene that the pole for the filling/emprying process is expectied to be located the following approximetions can be made.

$$
a_{\phi} \equiv \frac{\beta}{R T_{-\infty}}, b_{\phi} \equiv 0, \Delta \equiv\left|a_{\phi}-F_{\pi}\right|
$$

Under thase pprodinations the gas dyamic trassfor fuaction sipifies to

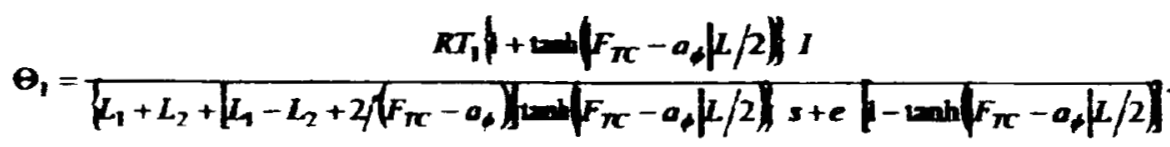

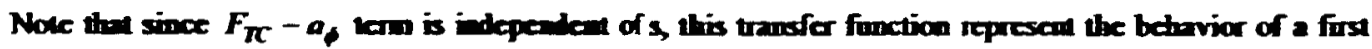
order systan with a choractistic tine of

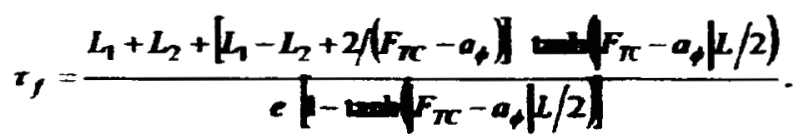

The thouling resposese for a throuling ratio of 12 of the mowe with the sure specifications is calculated with differen mathods and plotted in Figne 14. Figure shows the tine variation of the non-dinensiond pre-combation chamber pressure defined is $\left(P_{1}(p)-P_{1}^{i}\right)\left(P_{1}^{j}-P_{1}^{j}\right)$ where $P_{1}^{i}$ is the initiol provere and $P_{1}^{\prime}$ is the fol prosec. $T$ esering observation is the the pertubation solution will the filing time defined by cquation A.20 is i

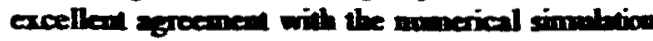
resul. This shoms thet equition A20 gives a good

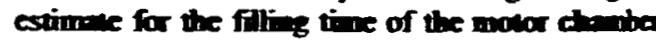
within the contex of the $2 \mathrm{~V}$-pon modet. The response acconting to the sinple trenter function is atso stown in Frgare 14. It is obvioes from the figure that the simple filling time agument for the hybrid coubustion chomber is non valid.
Anolha observition from fignre 14 is tha the maneriol simulution resil stows oscillatory behavior in the earty stages of the throteling crem. This oscillutary betavion is dac to the excitation of the acoustic modes of the cavity by the disturbence cased by the sadden increse in the oxidien mos flow race The cecillotion frequency and ile deoping tio scole of this mode of notion is concisten will the bogindian acoustic mode findiso for the sone noder.

This lind of betervior is commonty observad in AMROC DM-01 molas". Nunely, a nonlines disturbence carses the well duped oscillation of the durber pressore at the longitudinal acoustic frequencies. The exciting

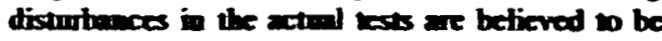
cansed by: 1) a sedden blockage of the nocale throw area by some disinczred fiel fractions, 2) the ignition of a balit of fuet oxidisa mixture 
captured in the pre-combustion chamber or 3) the low froquency oscillations of chamber pressure.

We compare the prefictions of our gas dynamic model for the acoustic frequencies of the chamber with the AMROC DM-01 motor lest dath Table 7 shows the first five longitudinal frequencies determinad by the perturbetion solutions. Since our model is isothermal, these frequescies are corrected by maliphying with the Eaceor of $\sqrt{r}$. An average $r$ value of 12 is wed for the calcubions Note thet the corrected froquencies falls it the ras of oberved fropuencies for every calenleded soo sic mode.

The gos dyouic cole developed to perform simalutions on the 2V-Port wodd is wood to confirm the fiodings of the perturbation solutions on the fraprency response of the system. In the sinnlations, siansoidal oxidiect moss flow rate inpuns at various frequencies are applied as the forcing fanction and the phese and the applinic of the ctamber prossere oscilltions at deteninged.

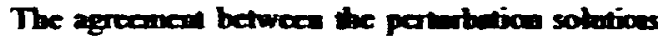
and the manarical simataions for the froprocay response of the system is also found to be satisfactory.

The simmlation code is los used bo inverignte the rapomse of the ges dy aric syseen

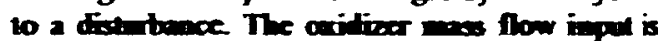

suddenly increased $10 \%$ above its cperating value and beld $a$ its eleveled level for 0.03 seconds before its suddenly reduced to its original value. The pressure time hisery for this simbion is shown Figure 15. It is clear that the disturbance excites the acoustic modes of the chamber simite to the previous observations. These exited modes decay in a modarice time scale as it was observed in the AMROC tests. A similar simulation is performed to determine the effea of nocale blockege on the stbility by redrcing the nomale thon ca for a bief period of tiace The ranlus for the nocede area pertutation case are idation

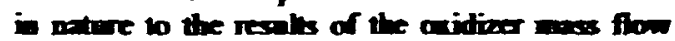

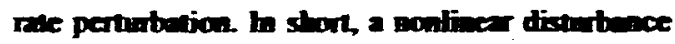
cases the ringing of the bybril chamber which decays in tine.

Finally a simple dety $\left(\tau_{M}\right)$ on the combustion resposse is appliad to the $g s$ dymemic system.

$$
F_{T C}=a_{1} n \bar{G}^{N-1} e^{-r_{M S}}
$$

Both the pertarbation solutions and also the nomerical simalbions indicate the any positive combustion detay brve negligible effect on the stability noture of the sysion.

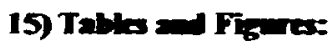

\begin{tabular}{|c|c|c|}
\hline 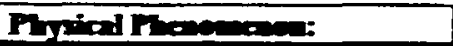 & I sole & Bindmin: \\
\hline 1) Solid phase kinetic tines & $\tau_{s p}<10^{-3} \sec$ & $\begin{array}{l}\text { Degenderion meclemisens of the } \\
\text { potymer }\end{array}$ \\
\hline 2) Gas phese kinetic tines & $\tau_{E p}<10^{-3} \sec$ & $\begin{array}{l}\text { Hydrocanbon combration } \\
\text { mect isms }\end{array}$ \\
\hline $\begin{array}{l}\text { 3) Feed systen response } \\
\text { times }\end{array}$ & $\begin{array}{l}\text { (Varies gradty from system bo } \\
\text { syco) }\end{array}$ & Resporse tine of the feed systan \\
\hline 4) Everpontion times & $\tau_{\exp }=f\left(U_{0}, T_{1}, \Delta P\right)$ & $\begin{array}{l}\text { Eveporation process of the lippid } \\
\text { oxidieca }\end{array}$ \\
\hline (5) Thernal bes in sotid & $\tau_{1} \propto \alpha / \dot{r}^{2}=10^{-1} \sec$ & $\begin{array}{l}\text { Themed profile chenges in the solid } \\
\text { gxin }\end{array}$ \\
\hline 6) Boundary byer diffusion tins & $\begin{array}{l}\tau_{B} \propto U / u_{e} \approx 10^{-1} \mathrm{sec} \\
\text { (Varies grealy fom case to casc) }\end{array}$ & 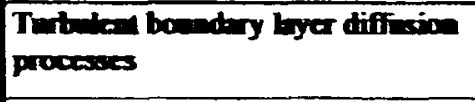 \\
\hline 3) Acoustic times (loogindian) & $\begin{array}{l}\tau_{a} \propto U / c \approx 10^{-3} \mathrm{sec} \\
(\mathrm{V} \text { aries greaty form case to case) }\end{array}$ & Prophefioe of be acoostic waves \\
\hline 7) Ces dye- mic filling times & 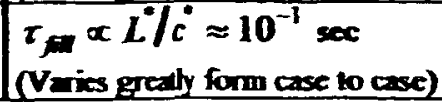 & Globel mass flow balonce \\
\hline
\end{tabular}

Table 1: The transien time scales of various phanomema in a typical bybrid rocket. Only the bast four are modeled in this puper. 


\begin{tabular}{|c|c|c|c|c|c|c|}
\hline $\begin{array}{c}\text { AMROC } \\
\text { Mete }\end{array}$ & $O / F$ & $\underset{(f / s o c)}{\dot{c}}$ & $\underset{(\mathrm{fls} / \mathrm{sec})}{\dot{*}}$ & $\underset{\text { (iin) }}{L^{\circ}}$ & $\underset{(H z)}{f}$ & $\begin{array}{c}T_{W R} \\
\left(m_{s e c}\right)\end{array}$ \\
\hline $\begin{array}{c}\text { S Motor } \\
\text { (10:) }\end{array}$ & 1.45 & 5584 & 5361 & 570 & 11 & 48.9 \\
\hline $\begin{array}{c}\text { Haif-Scale } \\
\text { (33A) }\end{array}$ & 1.45 & 5584 & 5361 & $1305-1430$ & 48 & 117.4 \\
\hline $\begin{array}{c}H-500 \\
(75)\end{array}$ & 1.45 & 5584 & 5361 & $1770-2340$ & 4.0 & 176.3 \\
\hline $\begin{array}{l}\text { DN-01 } \\
(250 \mathrm{k})\end{array}$ & 1.55 & 5700 & 5472 & 2168 & $2-3.5$ & 2048 \\
\hline
\end{tabular}

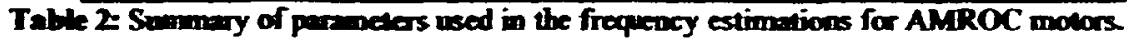

\begin{tabular}{|c|c|c|c|c|c|c|c|c|c|}
\hline $\begin{array}{l}\text { Teat } \\
\text { Ne. }\end{array}$ & $\begin{array}{c}\bar{D} \\
\text { (in) }\end{array}$ & $\begin{array}{c}\dot{m}_{0} \\
\text { (w/sec) }\end{array}$ & $\begin{array}{c}G_{0} \\
\left(\mathrm{~B} / \mathrm{in}^{2}-\right. \\
\mathrm{sec})\end{array}$ & $\begin{array}{c}G \\
\left(\mathrm{~W} / \mathrm{in}^{2}-\right. \\
\sec )\end{array}$ & $\begin{array}{c}P_{c} \\
(p \infty i)\end{array}$ & $O / F$ & $\begin{array}{c}f \\
(\mathbf{H z})\end{array}$ & $\begin{array}{r}\Delta P_{\text {asc }} \\
\left(\mathbf{x}_{0}\right)\end{array}$ & $\begin{array}{c}T_{W 2} \\
\text { (msec) }\end{array}$ \\
\hline $\begin{array}{c}1 \\
(\mathrm{GOX})\end{array}$ & 425 & 60 & 0.423 & 0571 & 600 & 285 & 13 & 200 & 48.8 \\
\hline $\begin{array}{c}2 \\
(c 0 x)\end{array}$ & 425 & 5.7 & 0.402 & 0541 & 550 & 289 & 8 & 300 & 47.2 \\
\hline $\begin{array}{c}7 \\
(G O X)\end{array}$ & 4.20 & 4.7 & 0339 & 0.458 & 440 & 289 & 15 & 100 & 44.7 \\
\hline$\stackrel{8}{8}$ & 422 & 5.1 & 0.365 & 0.492 & $260 / 280$ & 287 & 20 & 400 & 25.5 \\
\hline$\stackrel{1}{(\mathbf{O X})}$ & - & - & 0.222 & 0.31 & 435 & 251 & 8 & 250 & 662 \\
\hline
\end{tabular}

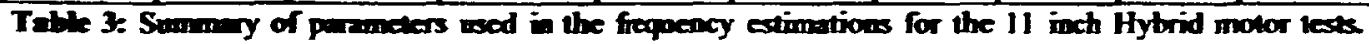
Grin lengh is 102 inches.

\begin{tabular}{|c|c|c|c|c|c|c|c|c|c|c|}
\hline $\begin{array}{l}\text { Teat } \\
\text { Na }\end{array}$ & $\begin{array}{l}\bar{D} \\
\text { (in) }\end{array}$ & $\underset{\text { (iin) }}{L}$ & $\begin{array}{c}\dot{m}_{0} \\
(\boldsymbol{m} / \mathrm{sec})\end{array}$ & $\begin{array}{c}G_{0} \\
\left(\mathrm{Ib} \sqrt{r^{2}} \mathbf{a}^{2}\right. \\
\sec )\end{array}$ & $\begin{array}{c}G, \\
\left(B, i^{2}\right. \\
i-s e c)\end{array}$ & $\begin{array}{c}P_{c} \\
(\mathbf{m i})\end{array}$ & $O / F$ & $\begin{array}{c}f \\
\left(H_{z}\right)\end{array}$ & $\underset{(\%)}{\Delta P_{\text {oxc }}}$ & $\begin{array}{c}T_{W 2} \\
(\mathrm{msec})\end{array}$ \\
\hline 3 & 3.4 & 102 & 3.44 & 0.38 & 0.527 & 745 & 26 & $6-10$ & 15 & 66.5 \\
\hline 4 & 43 & 102 & 3.36 & 0.23 & 0.325 & 325 & 24 & $10-20$ & 20 & 47.4 \\
\hline 6 & 3.7 & 102 & 836 & 0.78 & 1.024 & 750 & 32 & $10-15$ & 12 & 33.7 \\
\hline 7 & 5.3 & 102 & 3.41 & 0.15 & 0.22 & 335 & 2.1 & $6-15$ & 15 & 73.3 \\
\hline 8 & 5.7 & 102 & 387 & 0.15 & 0209 & 850 & 26 & $2-5$ & 60 & 191.7 \\
\hline 9 & 6.1 & 102 & 6.34 & 028 & 0.392 & 215 & 26 & $6-20$ & 33 & 25.9 \\
\hline 15 & 5.4 & 108 & 10.20 & 0.45 & 0599 & 1025 & 3.0 & 4 & 10 & 83.9 \\
\hline 10 & 6.1 & 102 & 593 & 020 & 0278 & 215 & 26 & $10-25$ & 5 & 36.5 \\
\hline
\end{tabular}

Table 4: Summary of prameters used in the frequency etinations for the NASAMSFC 11 inch Hybrid motor tests. 


\begin{tabular}{|c|c|c|c|c|c|c|c|c|}
\hline $\begin{array}{l}\text { Tet } \\
\mathrm{Na}\end{array}$ & $\begin{array}{l}\bar{D} \\
(\bar{D})\end{array}$ & $\stackrel{L}{L}$ & $\begin{array}{c}\dot{0} \\
(\mathrm{~B} i \sec )\end{array}$ & $\begin{array}{c}G_{0} \\
\left(b^{2}\right)^{2}- \\
\text { sec) }\end{array}$ & $\begin{array}{c}P_{r} \\
\text { (psi) }\end{array}$ & $O / F$ & $\begin{array}{c}f \\
(\mathrm{~Hz})\end{array}$ & $\left(\begin{array}{c}T_{W 2} \\
(m s c x)\end{array}\right.$ \\
\hline 1 & 20 & 27 & 3.44 & 0.29 & 500 & 4.0 & 19 & 20.6 \\
\hline
\end{tabular}

Table 5e Summary of parmenars used in the frequency estimations for the Arioona State Hybrid motor iest.

\begin{tabular}{|c|c|c|c|c|c|c|}
\hline Tet $\mathrm{K}$ & $\begin{array}{c}L \\
\text { (D) }\end{array}$ & $\frac{G_{0}}{\left(b r_{n^{2}-x e x}\right.}$ & $\begin{array}{c}P_{r} \\
(p-s)\end{array}$ & $O / F$ & $\begin{array}{c}f \\
(H z)\end{array}$ & $\begin{array}{c}T_{M 2} \\
\text { msec })\end{array}$ \\
\hline $4 F-4$ & 32 & 0.44 & 528.0 & 397 & 416 & 13.5 \\
\hline $4 F-5$ & 32 & 0.49 & 551.0 & 3.59 & 39.9 & 126 \\
\hline $4 F-1 b$ & 32 & 0.20 & 561.0 & 272 & 14.4 & 29.7 \\
\hline 4F1-c & 32 & 0.16 & 5420 & 3.06 & 13.6 & 36.1 \\
\hline $4 P-01$ & 45 & 0.39 & 318.0 & 269 & 408 & 123 \\
\hline $\mathbf{P}-02$ & 45 & 0.38 & 993.8 & 248 & 132 & 38.5 \\
\hline $4 P-03$ & 45 & 0.40 & 939.1 & 265 & 14.4 & 356 \\
\hline 4L-OB & 45 & 0.31 & 641.6 & 269 & 127 & 30.9 \\
\hline 4LOA & 45 & 0.52 & 6567 & 266 & 23.6 & 18.9 \\
\hline 4L-05 & 45 & 0.46 & 6493 & 272 & 19.1 & 212 \\
\hline 4L-08 & 45 & 0.44 & 525.0 & 264 & 23.3 & 17.9 \\
\hline 41-01 & 45 & 0.38 & 318.7 & 2.40 & 39.6 & 124 \\
\hline 4P-O4 & 45 & 0.21 & 159.1 & 1.73 & 424 & 10.7 \\
\hline $41-09$ & 45 & 0.26 & 265.3 & 1.54 & 20.3 & 13.7 \\
\hline $4 L-10$ & 45 & 0.43 & 590.0 & 2.89 & 27.0 & 182 \\
\hline 4L-11 & 45 & 0.11 & 2130 & 1.56 & 17.8 & 272 \\
\hline 4L-12 & 45 & 0.13 & 301.0 & 2.01 & 15.54 & 322 \\
\hline $4 \mathrm{NF}-01$ & 45 & 0.39 & 6022 & 27 & 2260 & 23.1 \\
\hline $4 N F-02$ & 45 & 0.22 & 600.4 & 234 & 11.10 & 40.4 \\
\hline 4NF-03 & 45 & 0.36 & 500.8 & 296 & 23.20 & 21.4 \\
\hline 4NF-04 & 45 & 0.48 & 568.5 & 3.01 & 3275 & 180 \\
\hline 4L-14 & 45 & 0.43 & 5245 & 251 & 25.15 & 180 \\
\hline 4ST-02 & 45 & 0.45 & 540.0 & 271 & 24.86 & 18.2 \\
\hline $4 L-15$ & 45 & 0.31 & 5555 & 2.09 & 14.94 & 26.2 \\
\hline ARcp-02 & 45 & 0.45 & 4023 & 263 & 36.49 & 13.5 \\
\hline
\end{tabular}

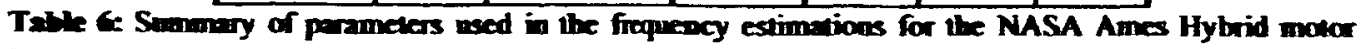
cests. 


\begin{tabular}{|c|c|c|c|c|}
\hline 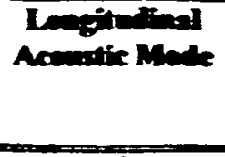 & 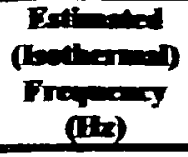 & 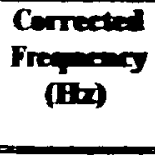 & $\begin{array}{l}\text { Oleerved } \\
\text { Frequens } \\
\text { (iib) }\end{array}$ & 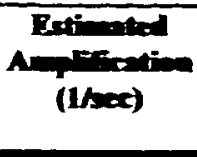 \\
\hline 1 & 48.4 & 53.0 & $50-55$ & -22 \\
\hline 2 & 967 & 103.9 & $100-110$ & -22 \\
\hline 3 & 1426 & 156.1 & $150-165$ & -21 \\
\hline 4 & 191.1 & 2093 & $200-200$ & -19 \\
\hline 5 & 240.7 & 2636 & $250-275$ & -18 \\
\hline
\end{tabular}

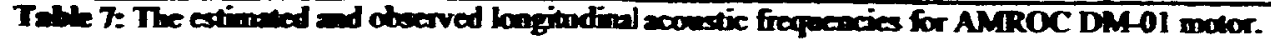

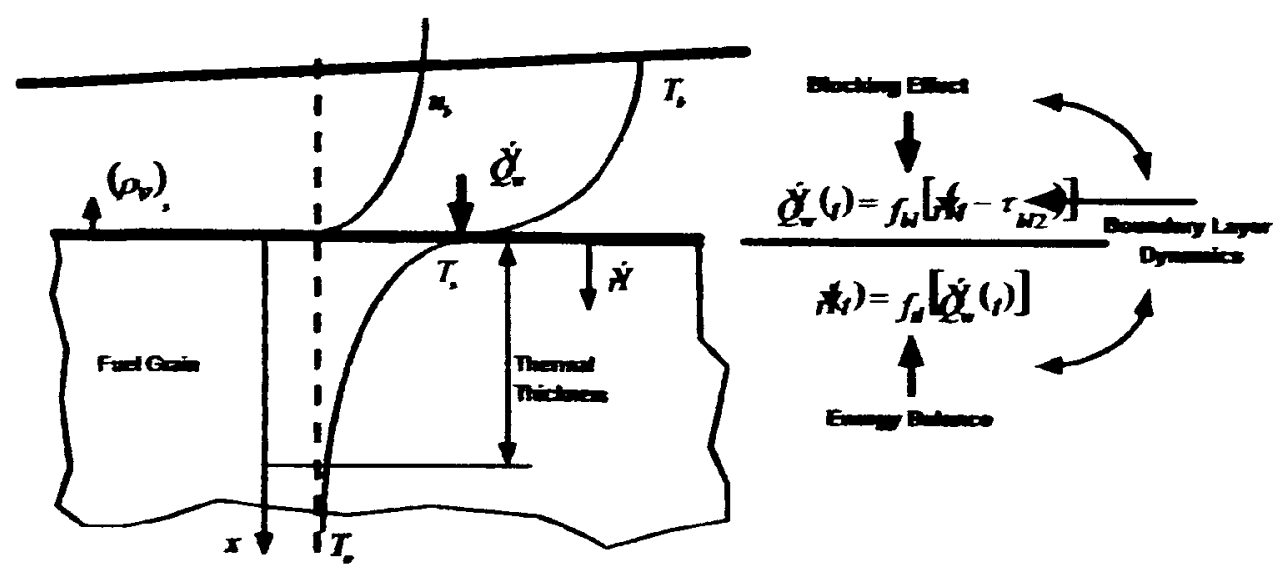

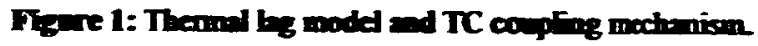

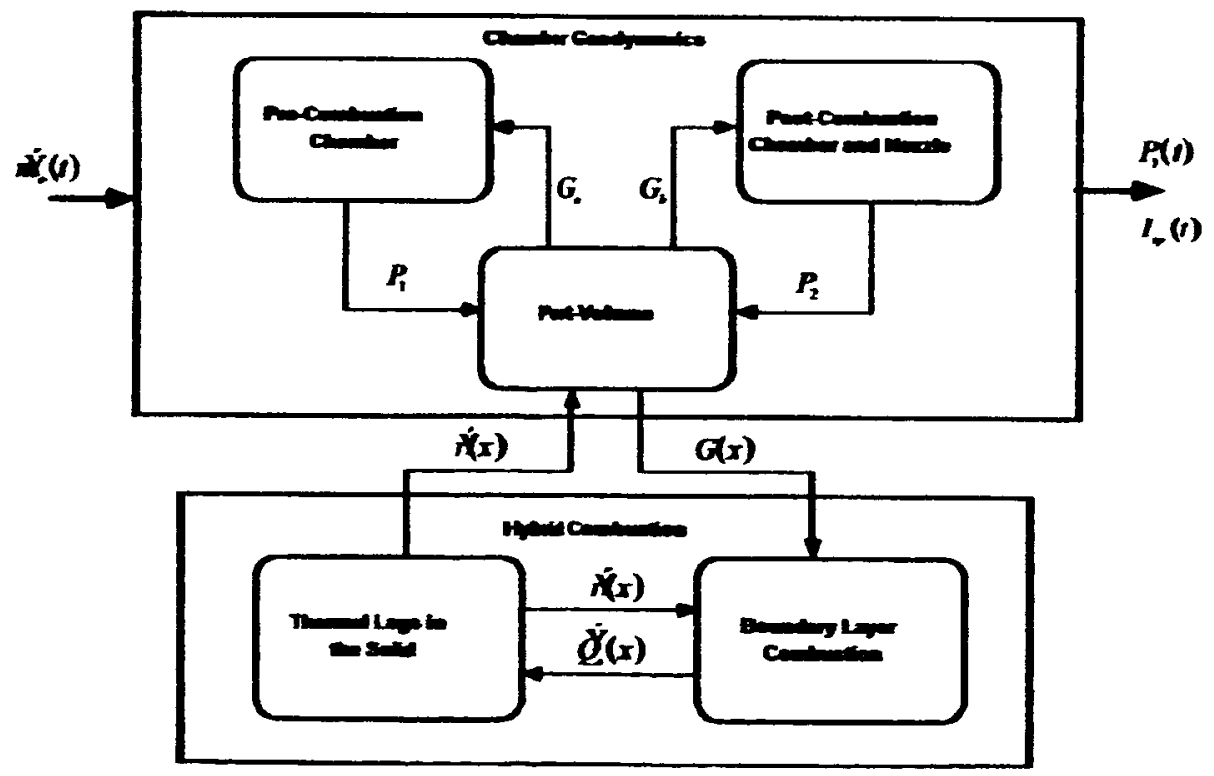

Figure 2. The schemic of the TCG coupled systan. 


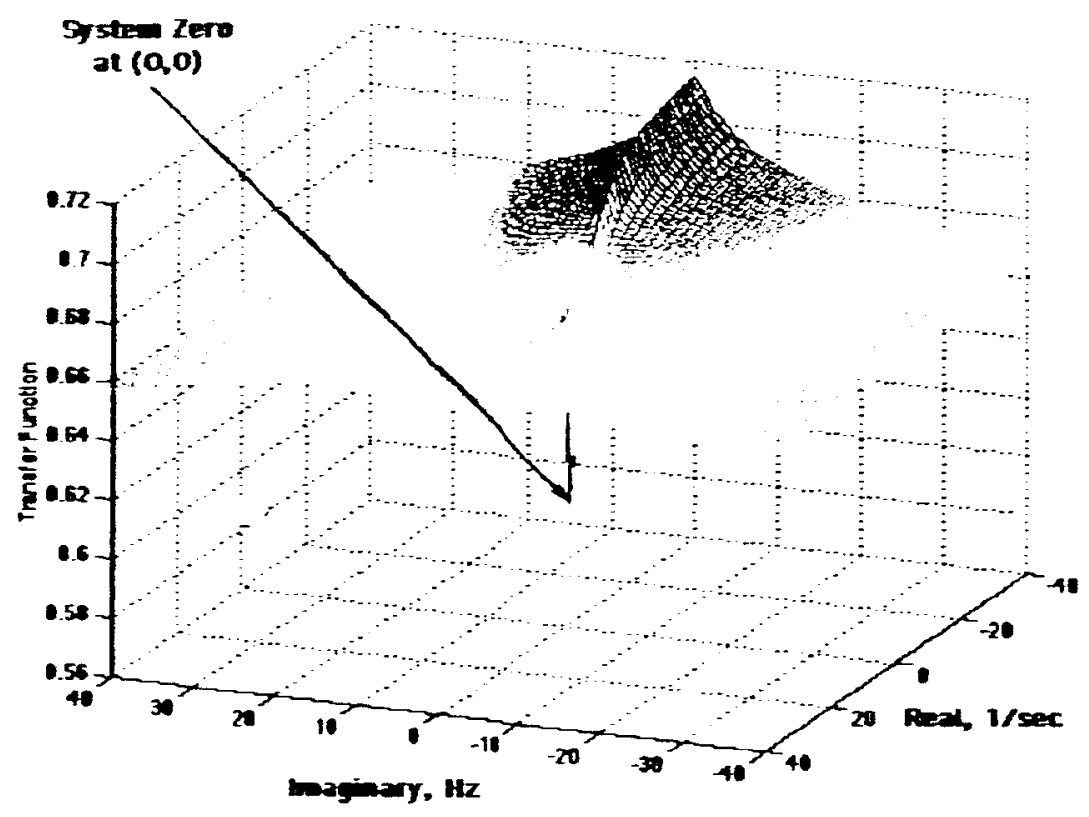

Figure 3: Plot of the transfer function of the TC coupled system with no delays $\left(\tau_{b n}=\tau_{b \prime 2}=0\right)$. This plot is for a HTPB system with $E_{a}=15$ kalmole.

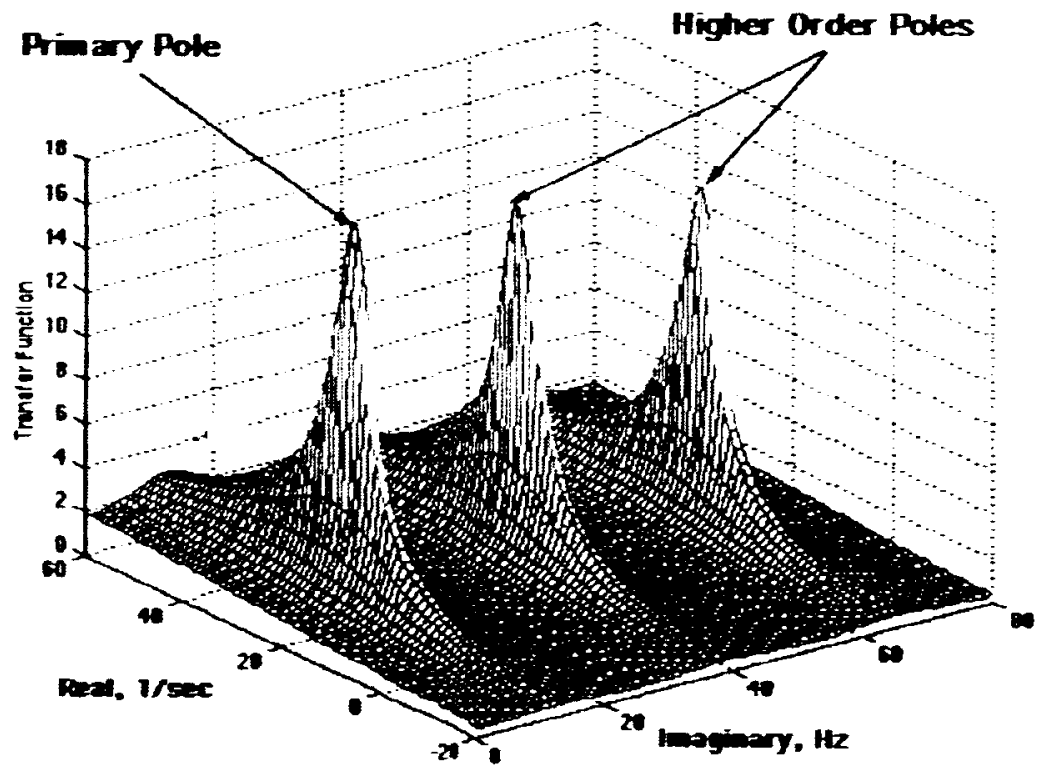

Figure 4: The unstable poles of the TC coupled system in the $s$ plane for $\tau_{W 1}=0, \tau_{W 2}=38$ msec. This plot is for a HTPB system with $E_{a}=15 \mathrm{kcal} / \mathrm{mole}$. 


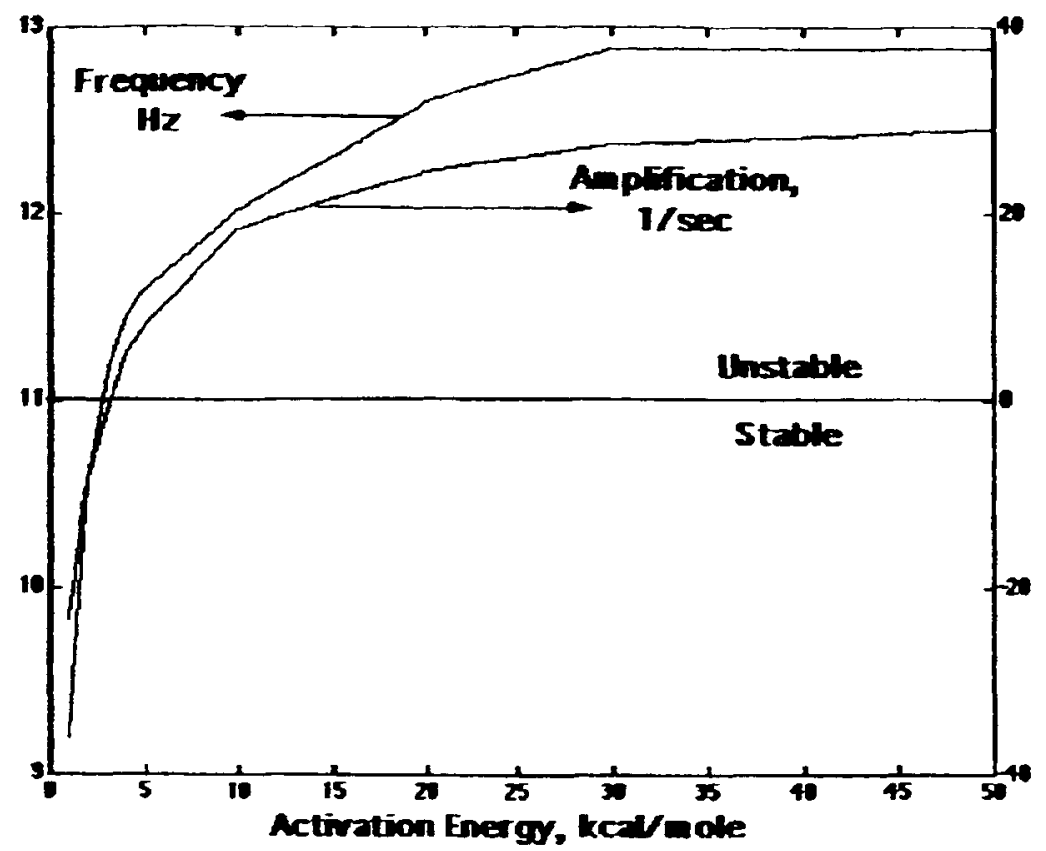

Figure 5e Effect of activation coerey on the oscithion frequency and aplifiction.

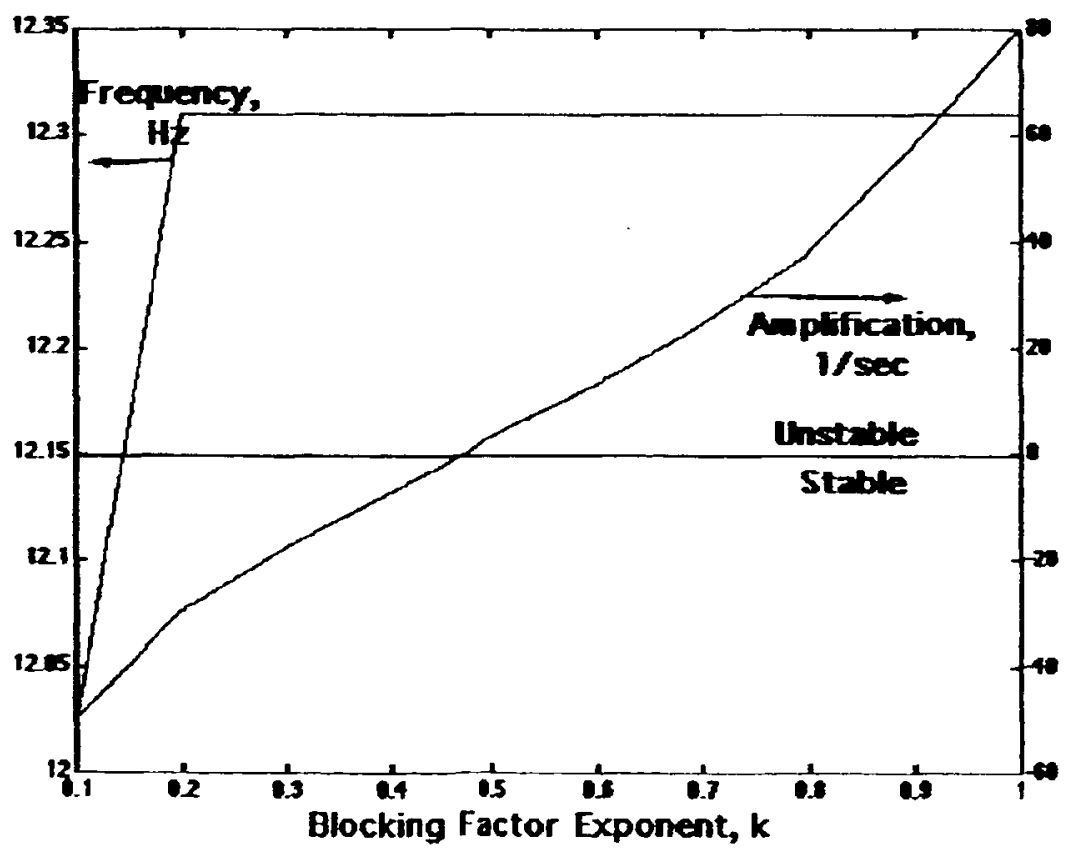

Figure 6: Eftect of blocking factor exponent on the oscillation frequency and amplification. 


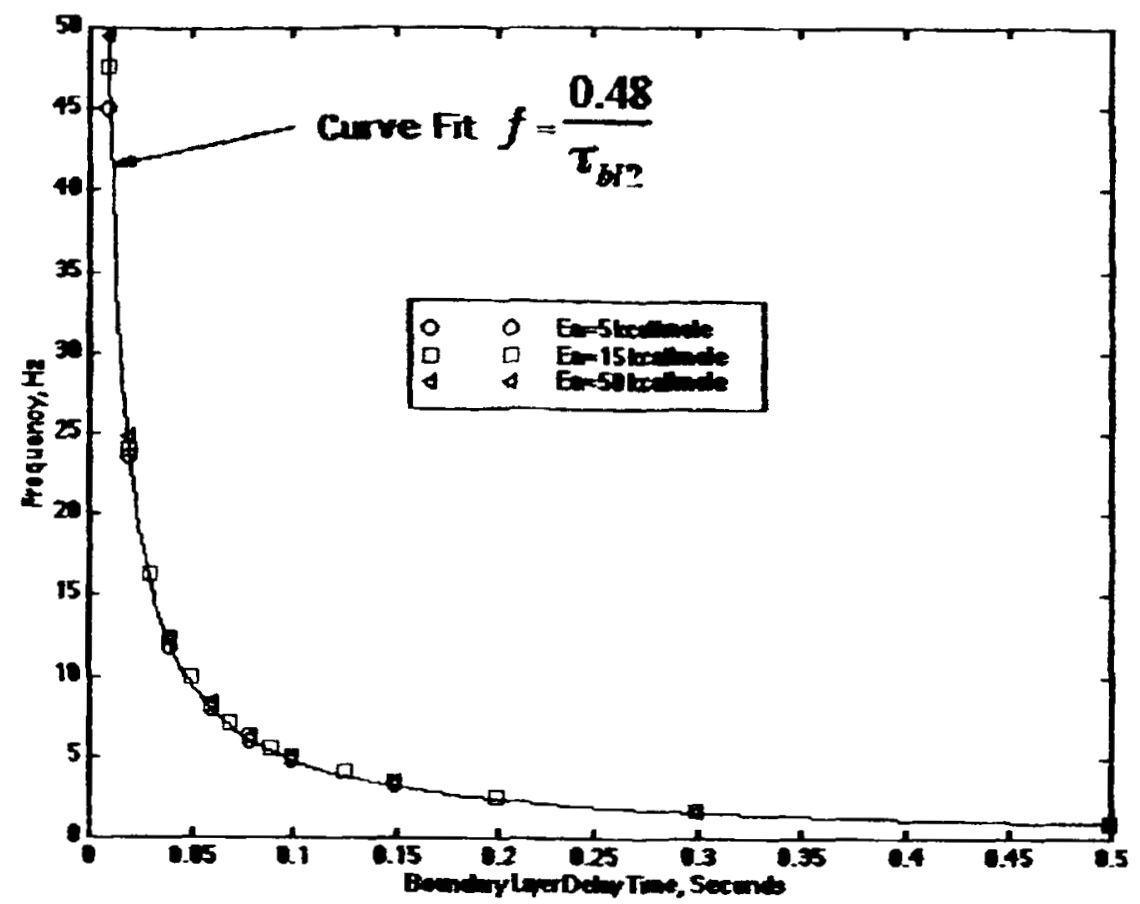

Figure 7: Effect of boundary byer delay time on the oscillation froquency for various activation energies.

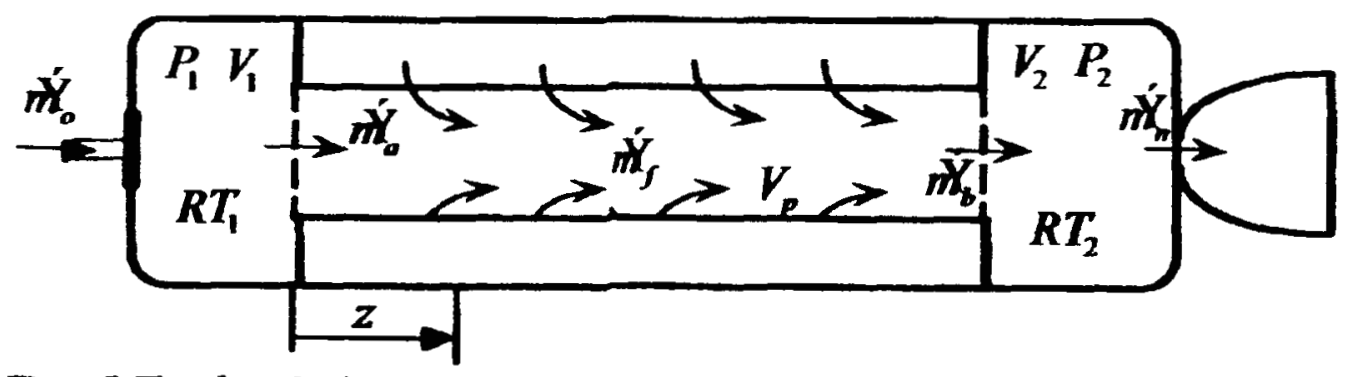

Figare 8 : The schandic of the $2 \mathrm{~V}$-port moded. 


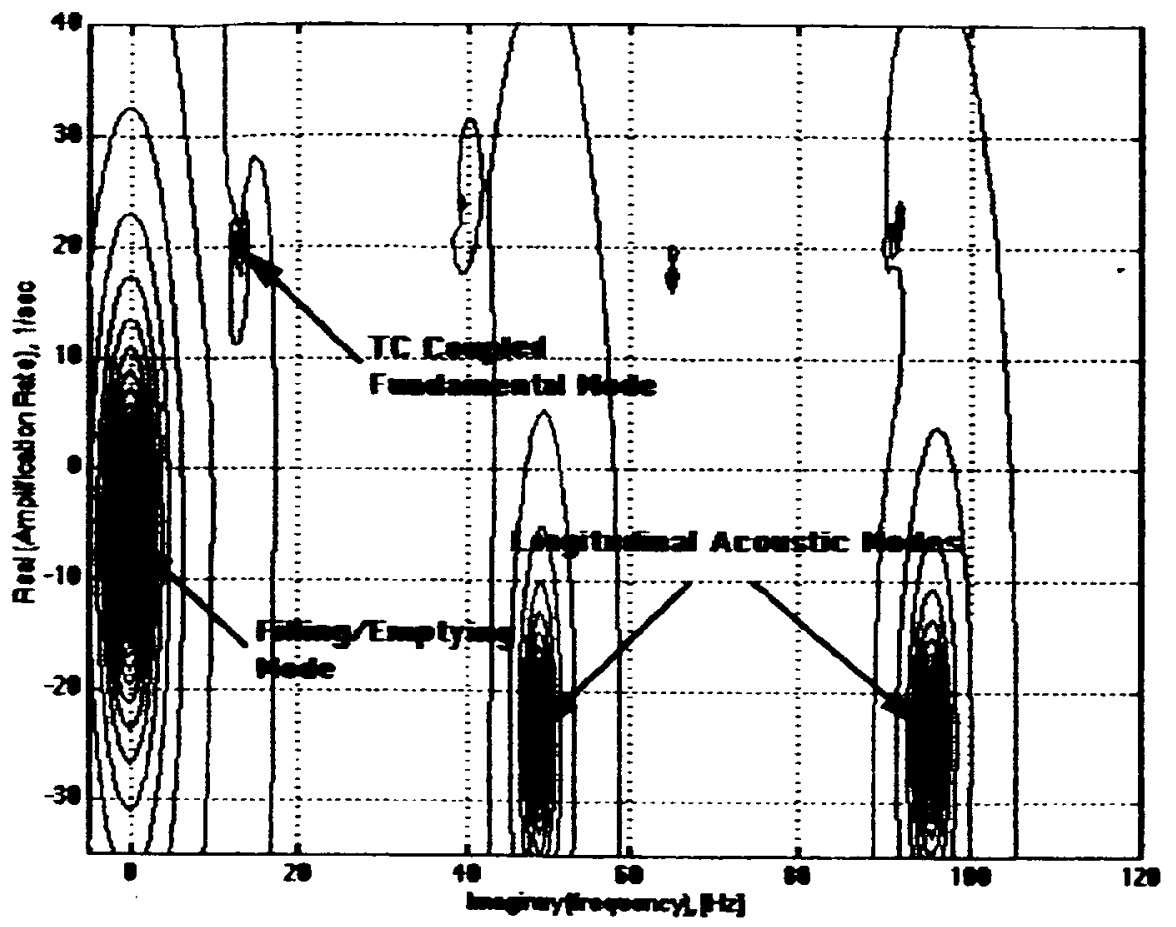

Figure 9: The contour plot of the TCG coupled system with $r_{W / 2}=38 \mathrm{msec}$. Most of the transient features of a hybrid system con be doduced from the locations of the poles.

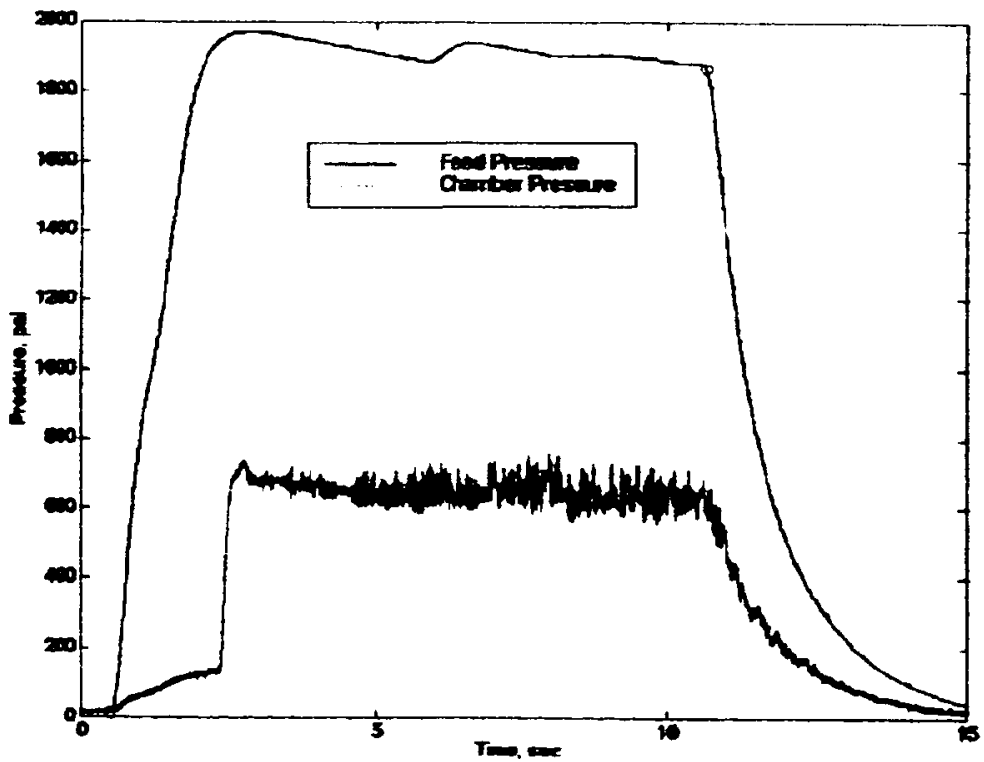

Figure 10: Chanber and foed pressure time traces for the paraffin-based motor test, 4L-05. 


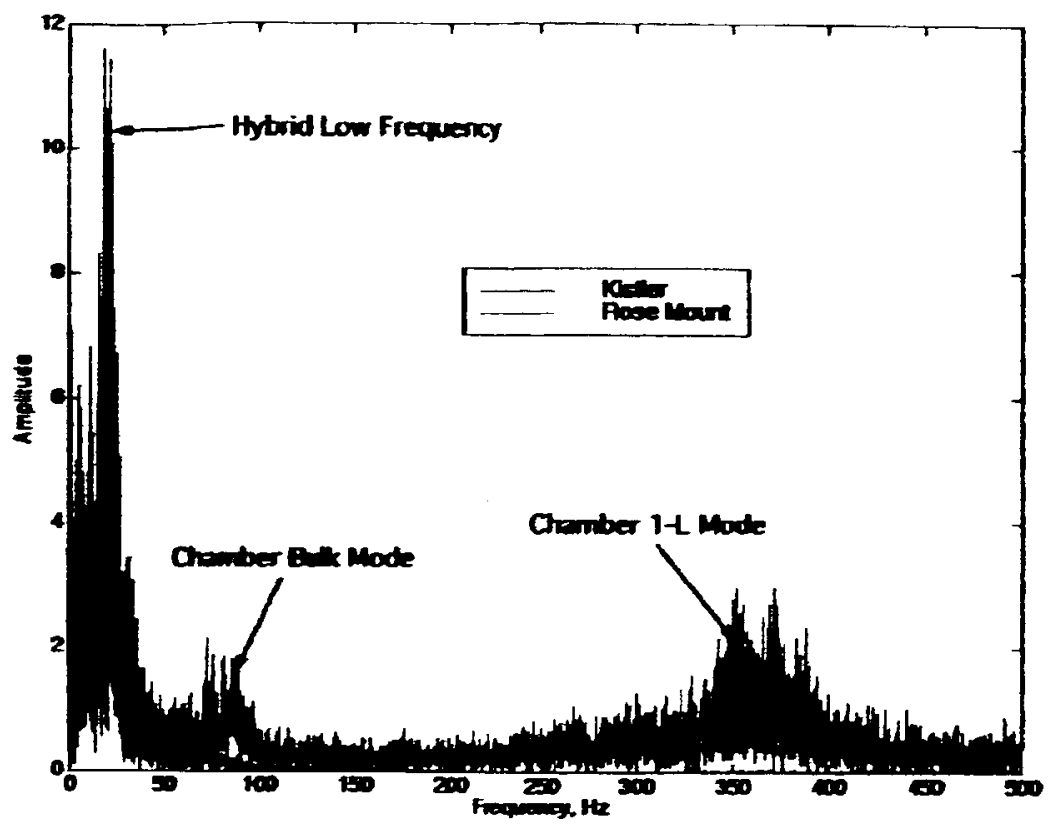

Flgure 11: Fourier transform of the chanber pressure for the paraffin-based motor test, 4L-05.

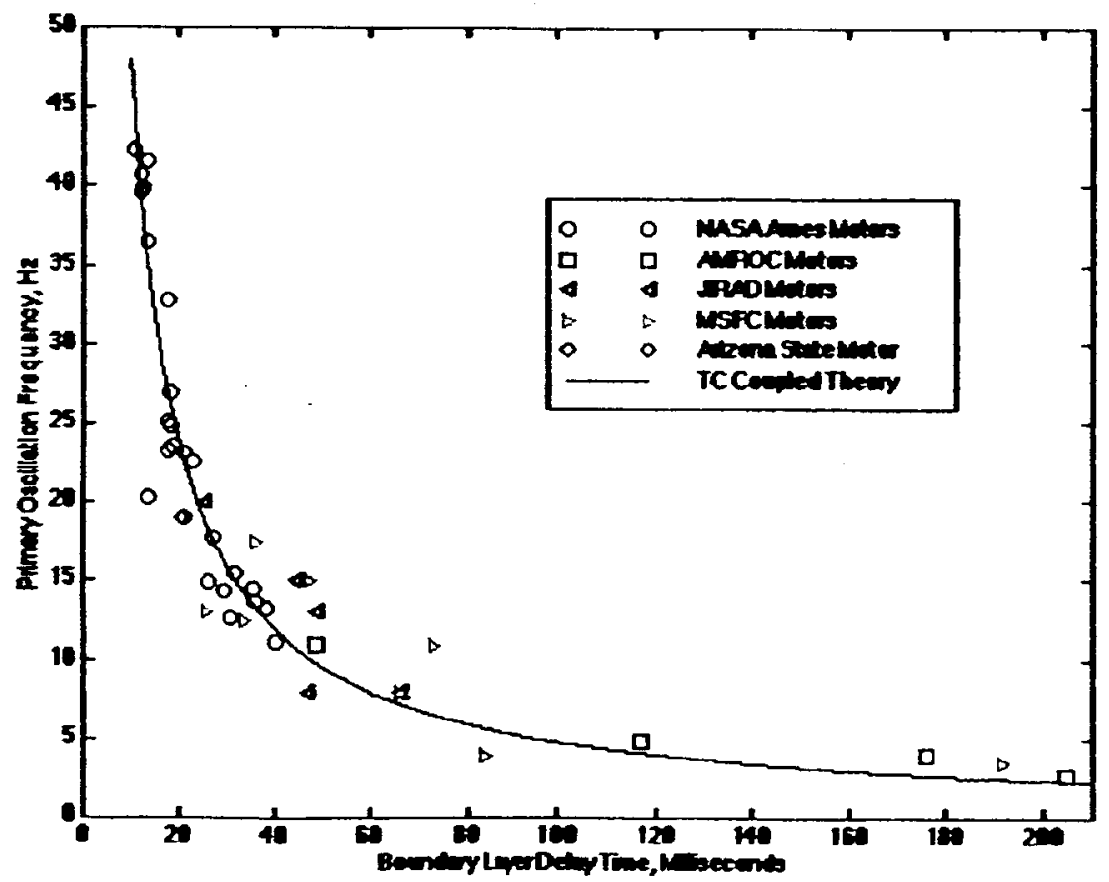

Figure 12: Compaison of the TCG coupled oscilletion frequency prediction with the hybrid molar test data available in the hiterime. 


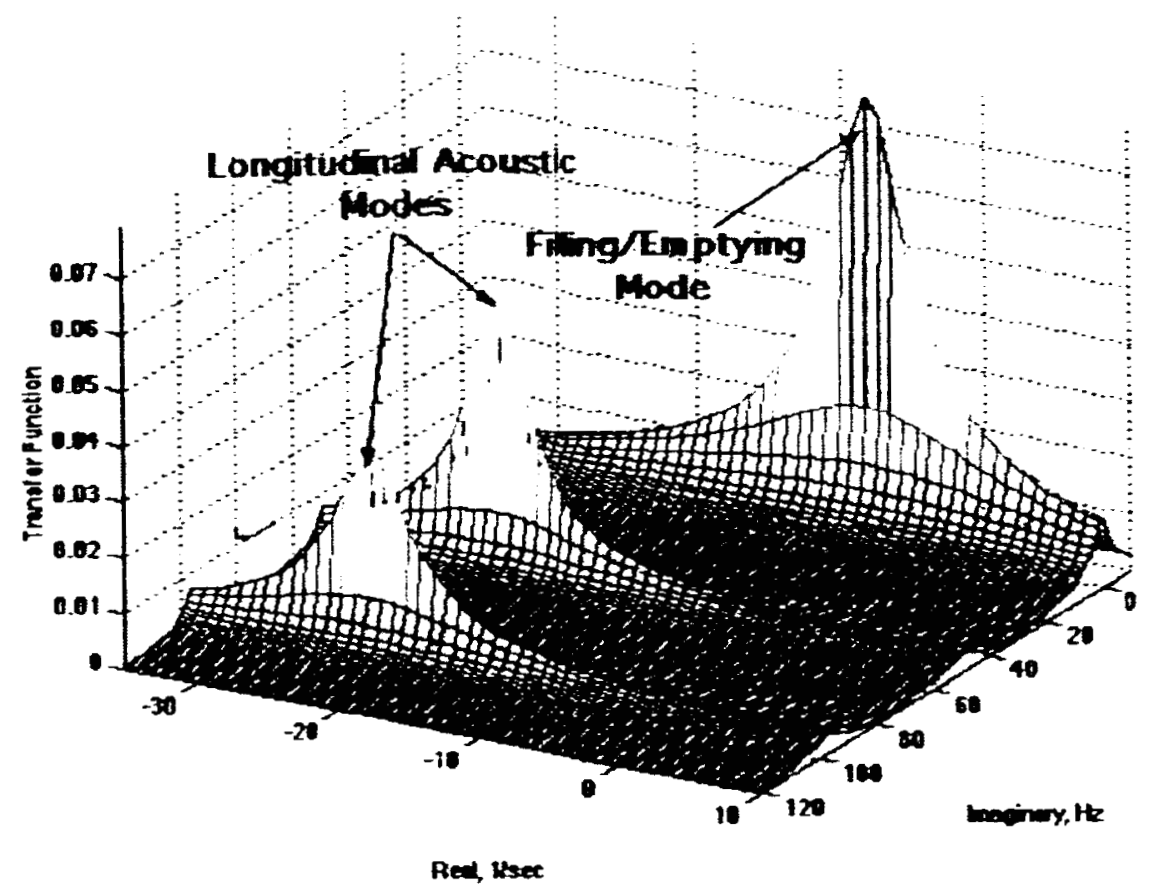

Figare 13: The plot of the transfer function for the pure gas dynamic system.

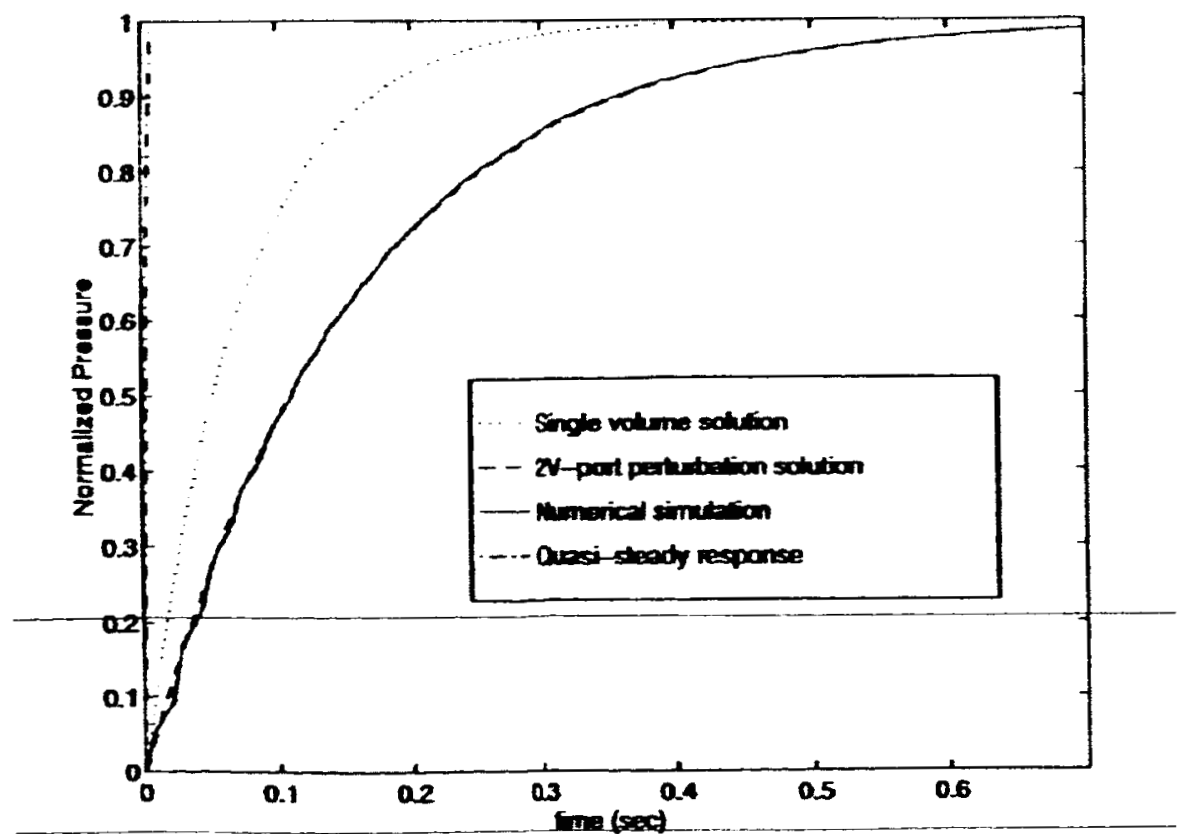

Fisure 14: The throting response for the pure gas dyamic system. 


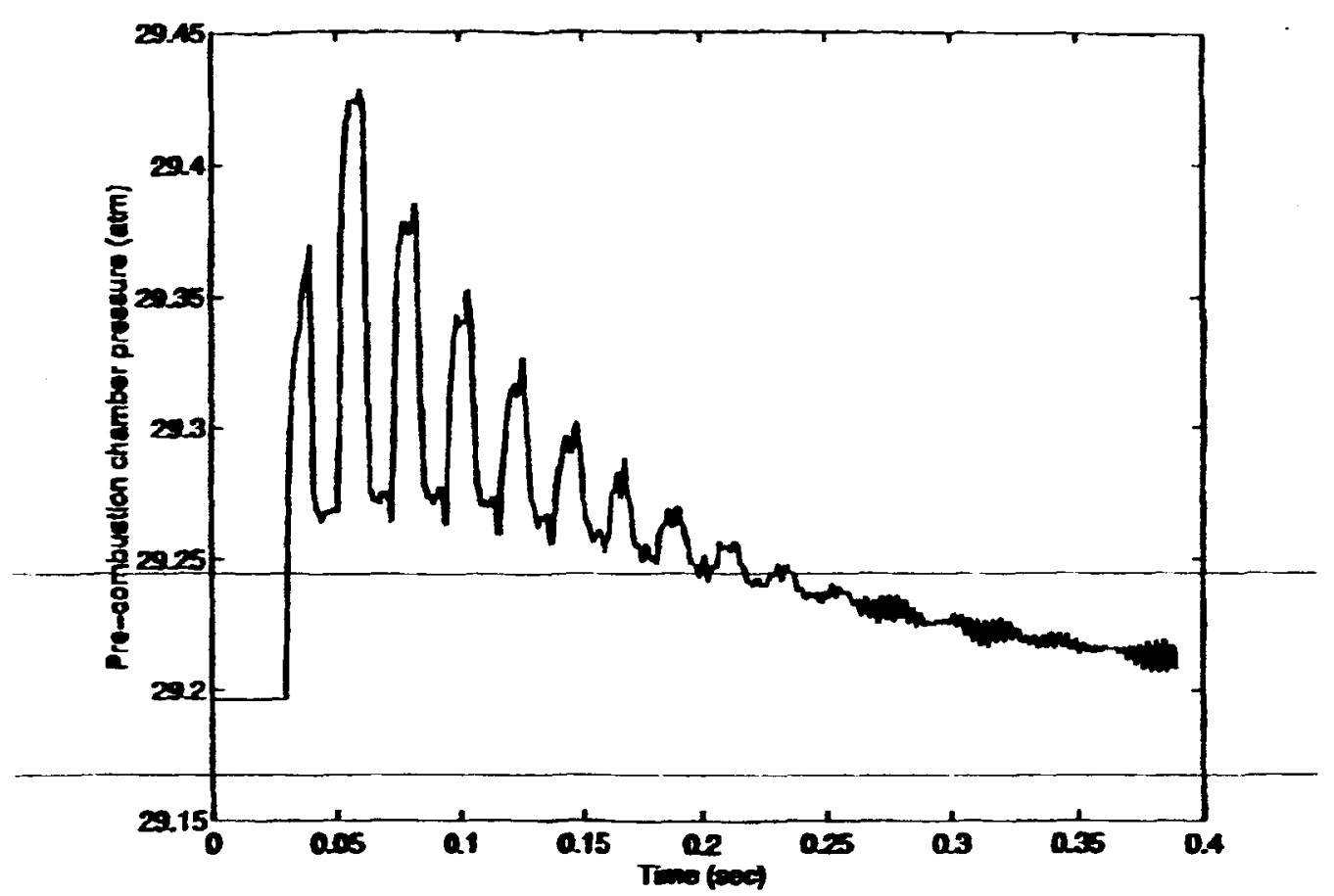

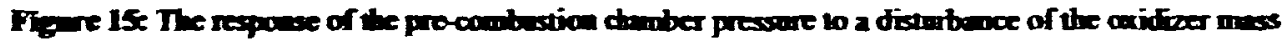
Jow rime. 